\title{
Direito Social: proibição de retrocesso e dever de progressão
}

\author{
Social Law: prohibition of kicking and duty of progress
}

\author{
MARCIA ANDREA BÜHRINGa
}

\begin{abstract}
RESUMO
Os direitos sociais estão expressamente previstos na Constituição Federal de 1988 , nos artigos $6^{\circ}$ ao $11^{\circ}$, no rol de direitos fundamentais sociais e também na ordem social, artigos 193 a 232, cuja função do Estado é garanti-los e concretizá-los, para que a coletividade possa usufruí-los e para não se correr o risco de retroceder no tempo, ou seja, voltar atrás nas conquistas já alcançadas, e sem que, com isso, signifique, violar a Constituição Federal, que representa a maior conquista histórica dos brasileiros. Por outro lado, o dever de progressiva realização, está abarcada em âmbito internacional, ou seja, nas cláusulas vinculativas de Direito Internacional com a priorização do dever de implantação efetiva, por meio dos pactos, tratados, acordos. São exemplos o direito à saúde, educação, trabalho, entre outros, que foram elevados à condição de direito social fundamental do ser humano, (em ambito interno e externo) de aplicação imediata e incondicionada.

Palavras-chave: Direitos sociais. Direito a prestações. Proibição de retrocesso. Direito subjetivo negativo. Dever de progressão. Direito a saúde, educação.
\end{abstract}

\begin{abstract}
Social rights are expressly provided for in the Federal Constitution of 1988, Articles 6 to 11, in the list of fundamental social rights and also in the social order, Articles 193-232, which function of the state is to guarantee them and implements them, that the community can enjoy them and not to take the risk to go back in time, that is, back in the gains already achieved, and without that, it, means, violating the Federal Constitution, which is the largest historic achievement of Brazilians. Moreover, the duty of progressive realization is embraced internationally, in other words, binding clauses in international law with the duty of effective prioritization of deployment, through agreements, treaties, conventions. Examples include the right to health, education, labor, among others, who were elevated to the status of fundamental social right of human beings, are (in internal and external scope) immediate and unconditional implementation.
\end{abstract}

Keywords: Social rights. Entitled to benefits. Prohibition of retrogression. Negative subjective right. Duty to progression. Right to health, and education.

\section{INTRODUÇÃO}

A Constituição Federal de 1988, contemplou os direitos sociais no artigo $6^{\circ}$, trouxe a educação, a saúde, a alimentação, o trabalho, a moradia, o lazer, a segurança, a previdência social, a proteção à maternidade e à infância, a assistência aos desamparados, logo no inicio junto ao Titulo I, dos Direitos e Garantias Fundamentais, assim como, contemplou os direitos sociais, no Titulo VIII, da Ordem Social, que tem como base o primado do trabalho, e como objetivo o bem-estar e a justiça sociais.

Os direitos sociais são direitos fundamentais, em prol da dupla fundamentalidade dos direitos sociais na ordem constitucional nacional, pois elevados à categoria de fundamental, vez que, a Constituição Federal de 1988 trouxe um conceito materialmente aberto de direitos fundamentais, de modo que é possível a inclusão de direitos não previstos no rol do art. 5ำ, como é o caso dos direitos sociais.

\footnotetext{
a Doutora pela PUCRS-Brasil. Mestre pela UFPR. Professora da PUCRS e UCS. <marcia.buhring@pucrs.br>. Ver também: BÜHRING, Marcia Andrea. Direitos humanos e fundamentais, migração nas fronteiras Brasil e Uruguai: uma análise dos déficits do direito social à saúde da mulher nas cidades gêmeas: Santana do Livramento-BR/Rivera-UR e Chuí-BR/Chuy-UR. Tese de Doutorado. PUCRS, Porto Alegre, 2013.
} 
A análise dos direitos sociais e a concretização desses implica em grandes desafios, pois envolve múltiplas variáveis, que podem ser econômicas, como orçamento, de políticas públicas específicas, deliberações do poder legislativo e executivo, portanto passa pela análise do mínimo existencial e da reserva do possível.

Se por um lado, a proibição de retrocesso guarda relação com a proteção e promoção dos direitos sociais em âmbito interno, e que foi expressamente acolhido pelo ordenamento jurídico nacional por meio do Pacto de São José da Costa Rica e por outro lado, também guarda relação com o dever de progressiva realização, de implantação efetiva, em âmbito internacional, por meio de pactos, acordos, a exemplo do Pacto Internacional de direitos sociais, econômicos e culturais.

Verificar-se-á também a temática na jurisprudencia nacional, a exemplo do posicionamento do Supremo Tribunal Federal; e estrangeira, a exemplo do Tribunal Constitucional da Alemanha e de Portugal, apresentados a seguir.

\section{DIREITOS SOCIAIS}

Os direitos sociais, de segunda dimensão, exigem atuação positiva do Poder Público para que na prática se verifique sua efetividade, a fim de buscar para todos a almejada igualdade social, que é própria do Estado Social de Direito, "não se identifica com a garantia de igualdade perante a lei, mera igualdade formal", mas material, ${ }^{1}$ que quer dizer a "superação da igualdade jurídica do liberalismo", vez que o próprio Estado se obriga "mediante retificação na ordem social, a remover as injustiças encontradas na sociedade", por meio, da elaboração legislativa, "que irá refletir as demandas dos excluídos dos benefícios da sociedade liberal", ${ }^{2}$ sendo que, atualmente é inconcebível uma estrutura social que seja estática, desvinculada do processo histórico, já advertia Miguel Reale, ${ }^{3}$ e cujo direito é uma determinação do futuro pelo passado.

Os direitos sociais estão expressamente previstos pela Constituição Federal de 1988 , nos artigos $6^{\circ}$ ao $11^{\circ}$, no rol de direitos fundamentais sociais e também na ordem social, artigos 193 a 232, e são por isso mesmo prestações positivas, como aduz José Afonso da Silva. ${ }^{4}$

Como dito, a Constituição Federal de 1988 elencou diversos direitos sociais, esses por sua vez, são direitos concernentes a uma prestação, pois tem por objeto uma conduta positiva estatal, para fornecer uma prestação de natureza fática, criando-a ou colocando-a a disposição daquele que detém esse direito. ${ }^{5}$ Existe assim, o reconhecimento do dever estatal na criação de pressupostos materiais, "essenciais à efetivação de tais garantias, e, simultaneamente, a faculdade do indivíduo de exigir imediatamente as prestações" que constituem seu direito. ${ }^{6}$ Vez que, normas constitucionais que reconhecem (direitos sociais de caráter positivo) implicam proibição de retrocesso, pois quando "uma vez dada satisfação ao direito, esse se transforma, nessa medida, em direito negativo ou direito de defesa, isto é, num direito a que o Estado se abstenha de atentar contra ele". 7

Ao que destaca Ingo Wolfgang Sarlet, por um lado, que os direitos a prestações em sentido amplo, são os "referentes à defesa da liberdade e igualdade, devendo o Estado atuar na proteção dos direitos fundamentais dos indivíduos contra intervenções impróprias por parte dos poderes públicos e particulares". E por outro lado, destaca o sentido estrito das prestações "que se vinculam aos ideais basilares de um Estado Social e consistem, basicamente, nos direitos a prestações materiais aos indivíduos destinatários". ${ }^{8}$ Tanto que ao Estado cumpre o dever de atuar, "quando o indivíduo não pode adquirir um bem ou serviço no mercado (saúde, educação, etc.) ou se é um serviço monopolizado e oferecido a todos (por exemplo, segurança pública)". ${ }^{9}$

É um erro dizer que direitos de liberdade são negativos e direitos sociais e econômicos são positivos, enfatiza George Marmelstein Lima. ${ }^{10}$

O ideal mesmo seria considerar que todos os direitos fundamentais pudessem ser analisados e compreendidos em suas múltiplas dimensões, ou seja: "a multidimensionalidade dos direitos fundamentais permite a superação da classificação dos direitos por status, desenvolvida por Jellinek", que "é uma das responsáveis pelo entendimento de que os direitos sociais não seriam verdadeiros direitos, mas simples declarações de boas intenções destituídas de exigibilidade". ${ }^{11}$

De maneira divergente, aduz Ricardo Lobo Torres, que existem obstáculos, entraves à consideração dos direitos sociais como sendo fundamentais, vez que, "sua dependência legislativa e do fato de que não fazem nascer, por si só, uma pretensão a prestações positivas estatais, uma vez que os direitos sociais são desprovidos de eficácia erga omnes e encontram-se subordinados a ideia de justiça social". ${ }^{12}$

Portanto, os direitos sociais, pela própria natureza, invocam do poder político uma "demanda de recursos para sua aplicabilidade plena, o que gera fortes pressões ideológicas e envolve escolhas políticas", que a própria Constituição Federal de 1988, refere enquanto objetivos, de uma sociedade livre, justa e solidária. ${ }^{13}$

A própria evolução constitucional contemporânea (em matéria de direitos fundamentais e do sistema 
internacional de tutela dos direitos humanos), tem demonstrado que "muitas constituições seguem refratárias à inserção de direitos sociais em seus textos", ${ }^{14}$ chega-se ao ponto, da própria negação da existência de direitos sociais, como o faz Fernando Atria, ${ }^{15}$ um absurdo, e nesse sentido o respaldo do argumento de Ingo Wolfgang Sarlet, quando refere que os direitos sociais são tanto prestacionais (portanto positivos) como defensivos (portanto negativos), ${ }^{16}$ e define os direitos sociais, informando que não estão vinculados única e exclusivamente à atuação positiva, mas também à negativa, ${ }^{17}$ portanto, os direitos sociais são sim fundamentais, em prol da dupla "fundamentalidade dos direitos sociais na ordem constitucional" nacional. ${ }^{18}$

Ademais, os direitos sociais têm propósitos compensatórios, como refere José Eduardo Faria, são "direito das preferências e das desigualdades", quer dizer, direito discriminatório com finalidade compensatória. ${ }^{19}$ Dessa feita, os direitos sociais constituíram categorias-chave: "Graças à mobilização da sociedade, as políticas sociais tornaram-se centrais, nessa década, na agenda de reformas institucionais que culminou com a promulgação da Constituição Federal de 1988". Tanto que os conceitos de direitos sociais, assim como universalização, ou mínimos sociais, dentre outros, "passaram, de fato a constituir categorias-chave norteadoras da constituição de um novo padrão de política social a ser adotado no país". ${ }^{20}$

Inaugura-se, pois, pós-Constituição de 1988 um leque de direitos sociais, rompendo com o modelo vigente de Estado e cidadania, com a extensão (ampliação) dos direitos sociais, ${ }^{21}$ são avanços para corrigir injustiças sociais, pautadas em duas características principais, de abertura, não são numerus clausus, ${ }^{22}$ permitem, a inclusão de outros direitos sociais que não estejam expressamente previstos na Constituição; e de implementação progressiva, cuja verificação prática deve respeitar os limites de orçamento existente. ${ }^{23}$

Vale a ressalva de que os direitos sociais, atualmente tem uma abertura material, portanto, não são taxativos, em termos práticos, direito à saúde, educação e seguridade são justamente os "mais reconhecidos no âmbito das constituições latino-americanas", com expressiva referência a família, crianças e a cultura. ${ }^{24}$

Dessa forma, pode-se mencionar que os direitos sociais são direitos fundamentais, ou seja, determinado direito elevado à categoria de fundamental, de acordo com as opções do legislador, sopesando bens jurídicos e atribuindo a positivação correspondente às normas de direitos fundamentais. ${ }^{25}$ Como se sabe, a Constituição Federal de 1988 trouxe um conceito "materialmente aberto de direitos fundamentais", de modo que é possível a inclusão de direitos não previstos no rol do art. 5ํㅡ, como é o caso dos direitos sociais, por exemplo, especificamente direito à saúde no Brasil.

Para Ingo Wolfgang Sarlet, todos os direitos sociais são direitos fundamentais, porque providos da fundamentalidade, ${ }^{26}$ tanto formal quanto material, em razão da própria permissão concedida pelo artigo $5^{5}$, $\S 2^{\circ}$, da CF, para inclusão de direitos fundamentais não constantes do rol do artigo $5^{\circ}$, aliado ao fato de que, os direitos sociais localizam-se, no texto constitucional, no título relativo aos direitos fundamentais. ${ }^{27}$

Interpretando-se o espírito do legislador à luz do artigo 5을 $\S 2^{\circ}$, da Carta Magna, verifica-se a intenção de que os direitos fundamentais não ficassem limitados aos expressamente previstos no texto constitucional, mas sim que houvesse um processo contínuo de extensão desses direitos. ${ }^{28}$ Visto que, a República Federativa, consiste num Estado Social e Democrático de Direito, razão pela qual lhe é intrínseca a existência e garantia de direitos fundamentais sociais, com vistas ao alcance da igualdade material, vez que, direitos fundamentais não podem existir "sem Estado ou, pelo menos, sem comunidade política integrada". ${ }^{29}$

Afirme-se: os direitos sociais não são meras normas programáticas, (muito embora, haja quem considere), ${ }^{30}$ não se pode encarcerar os direitos fundamentais sociais no conceito frágil e patético de normas programáticas, "uma vez que os valores sociais são os pilares do Estado Democrático de Direito". ${ }^{31}$

Até porque, entende-se por norma constitucional programática as que não receberam do constituinte uma "suficiente normatividade para que possam ser aplicadas, quando se faz necessário que a produção ordinária complete as matérias nelas traçadas", ${ }^{32}$ ou seja, aquela em que o constituinte não regula diretamente os interesses ou direitos, mas sim, limitase a definir princípios que sejam cumpridos pelos três Poderes "como programas das respectivas atividades, pretendendo unicamente a consecução dos fins sociais pelo Estado", ${ }^{33}$ pois, nem pelo fato de uma regra constitucional "contemplar determinado direito cujo exercício dependa de legislação integradora não a torna, só por isso, programática". ${ }^{34}$ Vale a menção de que regras, ${ }^{35}$ são diferentes de princípios jurídicos, ${ }^{36,37}$ ou seja, tomando como ponto de partida, a concepção de Robert Alexy, os princípios são mandados de otimização, cabe, portanto, interpretação de acordo com o caso concreto, enquanto as regras vêm previamente definidas (no texto constitucional) e não cabe qualquer interpretação. Dito de outra maneira, a Constituição Federal, além de ter a "tarefa de apontar para o futuro", mas principalmente tem função de proteger direitos 
arduamente conquistados, e por meio dos princípios constitucionais, sejam eles implícitos ou explícitos, "é possível combater alterações feitas por maiorias políticas eventuais, que legislando na contramão da programaticidade constitucional, retiram (ou tentam retirar) conquistas da sociedade". ${ }^{38}$

Os direitos e garantias individuais expressos no artigo 60, $4^{\circ}$, inc. IV, da Carta Magna, incluem, portanto, os direitos sociais, direitos de nacionalidade, cidadania e são alcançados pela proteção das cláusulas pétreas, mesmo de "titularidade individual, ainda que alguns sejam de expressão coletiva. É o indivíduo que tem assegurado o direito de voto, assim como é o indivíduo que tem direito à saúde". ${ }^{39}$

Isso levou a uma luta pela democratização do Estado, que intensificou debates sobre políticas públicas - de corte social, como informa Raquel Raichelis, vez que "este movimento põe em discussão não apenas o padrão histórico que tem caracterizado a realização das políticas sociais em nosso país - seletivo, fragmentado, excludente e setorizado", mas também, e principalmente a "necessidade de democratização dos processos decisórios responsáveis pela definição de prioridades e modos de gestão de políticas e programas sociais". ${ }^{40}$

Dir-se-ia mais, os direitos fundamentais custam dinheiro, e grandes são os desafios, no âmbito de suas concretizações, pois envolve pressupostos e requisitos de múltiplas variáveis, sejam elas econômicas, de disponibilidade orçamentária, de políticas públicas específicas as demandas, da deliberações por parte dos parlamentares, além de ações do próprio Poder Executivo. E, nesse sentido pergunta Cristina M. M. Queiroz, qual o limite. ${ }^{41}$

E justamente a eficácia ao implemento de políticas públicas faz com que a população tenha nas suas expectativas, uma promessa de concretização vez que, os direitos sociais "surgiram juridicamente como prerrogativas dos segmentos mais desfavoráveis - sob a forma normativa de obrigações do Executivo", além da intervenção proativa e subsequente dos poderes públicos. O que não pode acontecer, que os direitos sociais sejam puros e "simplesmente ser 'atribuídos' aos cidadãos", necessário sim que o Estado assuma o seu papel, que estabeleça políticas públicas "dirigidas a segmentos específicos da sociedade - políticas essas que têm por objetivo fundamentar esses direitos e atender às expectativas por eles geradas com sua positivação". ${ }^{42}$

As políticas públicas são metas a serem atingidas, são programas de ação estatal, que têm "como escopo a coordenação dos recursos disponíveis pelo Estado e também no que tange às atividades privadas com a finalidade de ações que possuam relevância que sejam politicamente determinados", ao que chama também de "metas coletivas conscientes". ${ }^{43}$ Para tanto, José Joaquim Gomes Canotilho bem afirma, que a positivação, restou importante nesse sentido. ${ }^{44}$

Essa positivação vem associada a reserva do possível, a dependência socioeconômica, ou ainda, os direitos na medida da lei, ou seja, constituem "direitos relativos por desencadearem sua plena eficácia e se tornarem exigíveis tão somente depois de concretizados pelo legislador". ${ }^{45}$

Por outro lado, sinaliza Jorge Miranda que os direitos sociais, não têm aplicação ou execução imediata, mas diferida, ou seja, são mais que "comandos-regras, explicitam comandos-valores.". ${ }^{46}$

Em vista disso, necessário se torna sim, a implementação progressiva de execução das políticas públicas para a realização desses direitos, depende da disponibilidade dos meios.

Contemporaneamente fala-se também em crise dos direitos fundamentais, e não apenas dos direitos sociais, com o aumento dos índices de exclusão social, crescente marginalização e criminalidade e "violência nas relações sociais em geral, acarretando, por sua vez, um número cada vez maior de agressões ao patrimônio, vida, integridade corporal, intimidade, dentre outros bens jurídicos fundamentais". ${ }^{47}$ É o que Flávia Piovesan chama de movimento de "esfacelamento de direitos sociais", mais precisamente uma violação constitucional, "são direitos intangíveis e irredutíveis, que são providos da garantia da suprema rigidez, o que torna inconstitucional qualquer ato que tenda a restringi-los ou aboli-los". ${ }^{48}$

Nesse passo, adverte-se também, a total ausência da dimensão social na agenda do MERCOSUL, que deixou para um segundo plano a dimensão social. ${ }^{49}$

Destaca ainda, Graciela Romero que há a existência de um consenso jurisprudencial e doutrinal sobre os direitos humanos reconhecidos nos pactos e tratados, que tem hierarquia constitucional..$^{50}$ Ao que se chega, a proibição do retrocesso (estando os direitos positivados ou não).

\section{PROIBIÇÃO DE RETROCESSO SOCIAL DEVER DE PROGRESSÃO}

O princípio da proibição de retrocesso não é novo, muito já foi escrito e discutido sobre a temática, porém, a abordagem histórica e conceitual em âmbito nacional e internacional; para afirmar-se que não se pode retroceder pura e simplesmente sem que isso acarrete responsabilidades, pois uma vez instituídos, são garantias e direitos. ${ }^{51}$ 
Vale a ressalva, de que os direitos de prestação passam a ser direitos subjetivos - daquelas pessoas que são beneficiados pelos programas sociais, e, portanto, perfectibiliza-se assim, o princípio do não retrocesso social. ${ }^{52}$

Por um lado, o princípio da proibição do retrocesso, pode ser entendido como direito subjetivo negativo em que o Estado tem o direito de se abster de atentar contra ele, por outro lado, a mera "subtração à livre e oportunística disposição do legislador, da diminuição de direitos adquiridos" como a prestação de saúde, representa uma violação do princípio (da confiança e da segurança)..$^{53}$

Lembra Luís Roberto Barroso que a vedação do retrocesso, embora não seja uma ideia recente, é "começa a ganhar curso na doutrina constitucional brasileira", ${ }^{54}$ que quer dizer, são ganhos sociais e econômicos, (que) "após serem realizados, jamais poderão ser ceifados ou anulados", são - garantia constitucional..$^{55}$ Embora, ainda "não esteja suficientemente difundido entre nós, tem encontrado crescente acolhida no âmbito da doutrina mais afinada com a concepção do Estado democrático de Direito", ${ }^{56}$ consagrada na Constituição Federal.

De plano, se invoca a leitura (e releitura) tangenciada por Ingo Wolfgang Sarlet, principalmente na abordagem do núcleo essencial e as observações que dizem respeito quanto à implementação de determinada prestação pelo Estado, (já tendo o direito sido concretizado). Quando esse não poderá, posteriormente ou mesmo arbitrariamente, retirar tal direito alcançado pelo indivíduo, ao que se denomina especificamente de "vedação do retrocesso social". ${ }^{57}$ Mas o que se entende por núcleo essencial? ${ }^{58}$

Constitui o núcleo essencial à vedação ao legislador de suprimir, a concretização de norma constitucional, "que trate do núcleo essencial de um direito fundamental social impedindo a sua fruição, sem que sejam criados mecanismos equivalentes ou compensatórios". Adverte ainda, que é proibido "o estabelecimento (ou restabelecimento, conforme o caso) de um vácuo normativo em sede legislativa". ${ }^{59}$

A proibição de retrocesso é um "limite dos limites dos direitos fundamentais sociais" refere Ingo Wolfgang Sarlet e não há como desvincular esse conceito de outro, que é o mínimo existencial. ${ }^{60,61}$

O Estado não pode se furtar dos deveres de concretizar o mínimo existencial, "de maximizá-lo e de empregar os meios ou instrumentos cabíveis para sua promoção, sob pena de a sociedade vir a experimentar uma imensa limitação no exercício de todos os seus direitos", ${ }^{62}$ portanto adverte ainda, Gilmar Ferreira Mendes, o núcleo essencial dos direitos fundamentais, "é a unidade substancial que, independentemente de qualquer situação concreta, estaria a salvo da decisão legislativa". 63

Ambas as teorias se completam, vez que não há a definição, a priori, do que seria núcleo essencial de um direito fundamental, pois não vem expresso na Constituição Federal, o que ocorre, (e precisa ocorrer) é uma "atuação da hermenêutica no caso concreto, que, objetivamente, trará a definição do que é essencial e mínimo para o direito em questão". ${ }^{64}$

Assim, o princípio da vedação do retrocesso, adverte Luis Roberto Barroso:

\begin{abstract}
por este princípio, que não é expresso, mas decorre do sistema jurídico-constitucional, entende-se que se uma lei, ao regulamentar um mandamento constitucional, instituir determinado direito, ele se incorpora ao patrimônio jurídico da cidadania e não pode ser arbitrariamente suprimido. Nessa ordem de ideias, uma lei posterior não pode extinguir um direito ou garantia, especialmente os de cunho social, sob pena de promover um retrocesso, abolindo um direito fundado na Constituição. O que se veda é o ataque à efetividade da norma, que foi alcançado a partir de sua regulamentação. Assim, por exemplo, se o legislador infraconstitucional deu concretude a uma norma programática ou tornou viável o exercício de um direito que dependia de sua intermediação, não poderá simplesmente revogar o ato legislativo, fazendo a situação voltar ao estado de omissão legislativa anterior. ${ }^{65}$
\end{abstract}

Ademais, existe uma relação umbilical entre a proibição do retrocesso social e os princípios, tanto da segurança jurídica como da dignidade da pessoa humana refere Ingo Wolfgang Sarlet. Observe-se, que a garantia da segurança jurídica não se esgota segundo o artigo $5^{\circ}$ inciso XXXVI da Constituição, na irretroatividade das leis, direito adquirido, coisa julgada e ato jurídico perfeito, nem mesmo na limitação ao poder constituinte derivado, mas sim, vai além, podendo atingir regras, que "possam implicar algum retrocesso social, frustrando legítimas expectativas de direito, criadas pelo próprio Estado ao concretizar direitos fundamentais proclamados na Lei Maior", porque a "segurança jurídica, na sua dimensão objetiva, exige um patamar mínimo de continuidade do Direito", de sorte que, na perspectiva subjetiva, "significa a proteção da confiança do cidadão nesta continuidade da ordem jurídica no sentido de uma segurança individual das suas próprias posições jurídicas". ${ }^{66}$

A dignidade da pessoa humana é o fundamento da República, significa, "sem transcendências ou metafísicas, o reconhecimento do homo noumenon, ou seja, do indivíduo como limite e fundamento 
do domínio político da República", ${ }^{67}$ apesar de o princípio do não retrocesso social não estar explícito, (a exemplo do princípio da dignidade da pessoa humana, que está), tem plena aplicabilidade, uma vez que é decorrente do sistema jurídico-constitucional, "entende-se que se uma lei, ao regulamentar um mandamento constitucional, instituir determinado direito, ele se incorpora ao patrimônio jurídico da cidadania e não pode ser absolutamente suprimido". ${ }^{68}$ Por conseguinte, a essencialidade do princípio da dignidade da pessoa humana, erigida como princípio norteador da Constituição, é cânone constitucional "que incorpora as exigências de justiça e dos valores éticos, conferindo suporte axiológico a todo o sistema jurídico brasileiro". ${ }^{69}$

Dessa feita, a dignidade da pessoa humana, na sua condição de "premissa antropológica" 70 do Estado Constitucional, implica dever do Estado de "impedir que as pessoas sejam reduzidas à condição de mero objeto no âmbito social, econômico e cultural", pois se exige um mínimo de direitos sociais, que sejam capazes de efetivar a "participação do cidadão no processo democrático-deliberativo de uma autêntica sociedade aberta". ${ }^{71}$

Sem dúvida existe forte e inquestionável conexão entre a proibição de retrocesso e a segurança jurídica, e outros princípios ou mesmo outros institutos jurídico constitucionais, como a proporcionalidade e razoabilidade, ou ainda, com própria dignidade da pessoa humana. ${ }^{72}$ Observe-se que a vedação do retrocesso social é a possibilidade de invalidar a revogação de normas que, "regulamentando o princípio, concedam ou ampliem direitos fundamentais, sem que a revogação em questão seja acompanhada de uma política substitutiva equivalente". ${ }^{73}$

Ao mesmo tempo em que a proibição de retrocesso guarda relação com a proteção e promoção dos direitos sociais em âmbito interno, guarda relação também com o dever de progressiva realização, em âmbito internacional, contido em cláusulas vinculativas de Direito Internacional priorização do dever de implantação efetiva, (a exemplo do Pacto Internacional de direitos sociais, econômicos e culturais, de 1966) de uma "ampliação de uma cidadania inclusiva". ${ }^{74}$

Da aplicação progressiva desses direitos, resulta a cláusula de proibição do retrocesso social em matéria de direitos sociais, considera Flávia Piovesan:

Se os direitos civis e políticos devem ser assegurados de plano pelo Estado, sem escusa ou demora - têm a chamada auto-aplicabilidade, os direitos sociais, econômicos e culturais, por sua vez, nos termos em que estão concebidos pelo Pacto, apresentam realização progressiva. [...] No entanto, cabe realçar que tanto os direitos sociais, como os direitos civis e políticos demandam do Estado prestações positivas e negativas, sendo equivocada e simplista a visão de que os direitos sociais só demandariam prestações positivas. $^{75}$

Por outro lado, importante referir que o princípio da proibição do retrocesso foi expressamente acolhido pelo ordenamento jurídico nacional por meio do Pacto de São José da Costa Rica e "caracteriza-se pela impossibilidade de redução dos direitos sociais amparados na Constituição, garantindo ao cidadão o acúmulo de patrimônio jurídico". ${ }^{76}$ Ou seja, a vedação de retrocesso social na ordem democrática, especialmente em matéria de direitos fundamentais sociais, "pretende evitar que o legislador infraconstitucional venha a negar (no todo ou em parte essencial) a essência da norma constitucional, que buscou tutelar e concretizar um direito social resguardado em seu texto". ${ }^{77}$

Registre-se por oportuno, que tanto o Pacto Internacional sobre Direitos Econômicos, Sociais e Culturais, como o Protocolo de San Salvador, consagra o princípio da progressividade como evolução na implantação dos direitos sociais.

Também a Convenção Americana de Direitos Humanos de 1969, afirma Carlos Weis, "apesar de a teoria tradicional dos direitos humanos preconizar que as liberdades demandam uma abstenção estatal", o que se vê é o texto americano "filiar-se à corrente moderna, segundo a qual o importante é garantir a observância de todos os direitos humanos, pouco importando natureza das medidas necessárias para garantir sua efetividade máxima". 78

Na seara jurisprudencial não é diferente, tendo sido o princípio da proibição do retrocesso, utilizado inúmeras vezes, depois da primeira menção em 17/02/2000, por meio da Ação Direta de Inconstitucionalidade (ADI no 2.065-DF), de relatoria, do Ministro Sepúlveda Pertence: veja-se parte do voto pela importância (ainda que não vinculado diretamente ao direito à saúde), essa ADI questionava a constitucionalidade de dispositivos legais que extinguiam os Conselhos municipais e estaduais da Previdência Social.

[...] quando, já vigente a Constituição, se editou norma integrativa necessária à plenitude da eficácia [da norma constitucional], pode subseqüentemente o legislador, no âmbito de sua liberdade de conformação, ditar outra disciplina legal igualmente integrativa do preceito constitucional programático ou de eficácia limitada; mas não pode retroceder - sem violar a Constituição - ao 
momento anterior de paralisia de sua efetividade pela ausência da complementação legislativa ordinária reclamada para implementação efetiva de uma norma constitucional. [...] Com o admitir, em tese, a inconstitucionalidade da regra legal que a revogue, não se pretende emprestar hierarquia constitucional à primeira lei integradora do preceito da Constituição, de eficácia limitada. Pode, é óbvio, o legislador substituí-la por outra, de igual função complementadora da Lei Fundamental; o que não pode é substituir a regulação integradora precedente - pré ou pós constitucional - pelo retorno ao vazio normativo que faria retroceder a regra incompleta da Constituição à sua quase completa impotência originária. (ADI no 2065-0/DF, voto do Ministro Sepúlveda Pertence) ${ }^{79}$ (grifou-se)

Ou seja, a menção expressa a esse novo princípio de não poder retroceder sem que isso significasse violar frontalmente a Carta Política de 1988, pode o legislador, baseado na sua "liberdade de conformação, ditar outra disciplina legal igualmente integrativa do preceito constitucional programático ou de eficácia limitada: mas não pode retroceder - sem violar a Constituição" ${ }^{80} \mathrm{O}$ que representou um marco, datado de 2000, quando efetivamente passou a se ver com bons olhos, (depois que muitos doutrinadores, a exemplo dos Ministros do Supremo Tribunal Federal, de Ingo Wolfgang Sarlet, Luiz Roberto Barroso, entre outros, passaram a amplamente discutir a temática e aplicá-la nas decisões).

Os avanços sociais alcançados (experimentados) pelos indivíduos, e a coletividade de modo geral, não poderão retroceder, é o que se constata de outro julgamento importante em ARE 639337, cujo Relator foi Min. Celso de Mello em 2011. Veja-se:

[...] A PROIBIÇÃO DO RETROCESSO SOCIAL COMO OBSTÁCULO CONSTITUCIONAL À FRUSTRAÇÃO E AO INADIMPLEMENTO, PELO PODER PÚBLICO, DE DIREITOS PRESTACIONAIS. - O princípio da proibição do retrocesso impede, em tema de direitos fundamentais de caráter social, que sejam desconstituídas as conquistas já alcançadas pelo cidadão ou pela formação social em que ele vive. - A cláusula que veda o retrocesso em matéria de direitos a prestações positivas do Estado (como o direito à educação, o direito à saúde ou o direito à segurança pública, v.g.) traduz, no processo de efetivação desses direitos fundamentais individuais ou coletivos, obstáculo a que os níveis de concretização de tais prerrogativas, uma vez atingidos, venham a ser ulteriormente reduzidos ou suprimidos pelo Estado. Em conseqüência desse princípio, o Estado, após haver reconhecido os direitos prestacionais, assume o dever não só de torná-los efetivos, mas, também, se obriga, sob pena de transgressão ao texto constitucional, a preservá-los, abstendo-se de frustrar - mediante supressão total ou parcial - os direitos sociais já concretizados.[...]. ${ }^{81}$

Frise-se: o princípio da proibição do retrocesso impede, em tema de direitos fundamentais de caráter social, que sejam desconstituídas as conquistas já alcançadas pelo cidadão.

Aponta Ingo Wolfgang Sarlet, que a proibição de retrocesso em matéria de direitos sociais (mesmo não ter sido expressamente acolhida por nenhuma das constituições latino-americanas), representa contemporaneamente "uma categoria reconhecida e em processo de crescente difusão e elaboração doutrinária e jurisprudencial em várias ordens jurídicas, inclusive em função da sua consagração no âmbito do Direito Internacional dos direitos humanos". 82

Convém ressaltar exemplificativamente que na Alemanha, a aplicação do princípio da proibição de retrocesso social tem íntima conexão com o princípio da segurança jurídica, e aduz Felipe Derbli, que o tratamento da proibição de retrocesso social na experiência alemã "inicia-se ainda sob o pálio da discussão a respeito da eficácia dos direitos fundamentais sociais, particularmente os de cunho prestacional, e da sua plena sindicabilidade em juízo". 83

Também exemplificativamente em Portugal, (e aqui vale o registro, diferentemente da Alemanha), a "sindicabilidade jurídica dos direitos econômicos, sociais e culturais - pode ser extraída diretamente da Constituição Portuguesa" (e da legislação infra), ${ }^{84} \mathrm{a}$ uma determinada concepção de direitos sociais e, mais "concretamente, aos direitos sociais como elemento do princípio socialista presente na versão originária da Constituição de 1976". ${ }^{85}$

Para tanto, traz-se a menção importante ao acórdão de no 39/84, do Tribunal Constitucional português, que segundo Lênio Luiz Streck invalidou a revogação de boa parte da Lei do Serviço Nacional de Saúde do país, frise-se: invalidou

[...] a partir do momento em que o Estado cumpre (total ou parcialmente) as tarefas constitucionalmente impostas para realizar um direito social, o respeito constitucional deste deixa de consistir (ou deixa de consistir apenas) numa obrigação negativa. O Estado, que estava obrigado a atuar para dar satisfação ao direito social, passa a estar obrigado a abster-se de atentar contra a realização dada ao direito social. 
Note-se que o Tribunal Constitucional Português ao proferir o Acórdão é considerado um verdadeiro leading case em matéria de saúde. Vejam-se abaixo trechos do relator, Vital Moreira:

A Constituição não se bastou com estabelecer o direito à saúde. Avançou no sentido de anunciar um conjunto de tarefas estaduais destinadas a realizá-lo. À frente delas a lei fundamental colocou a "criação de um serviço nacional de saúde" (artigo 64은 no 2). A criação de um serviço nacional de saúde é pois instrumento - o primeiro - de realização do direito à saúde. Constitui por isso elemento integrante de um direito fundamental dos cidadãos, e uma obrigação do Estado. Ao extinguir o Serviço Nacional de Saúde, o Governo coloca o Estado, de novo, na situação de incumprimento da tarefa constitucional que lhe é cometida pelo artigo 640, $n^{\circ} 2$ da Constituição. Que o Estado não dê a devida realização às tarefas constitucionais, concretas e determinadas, que lhe estão cometidas, isso só poderá ser objecto de censura constitucional em sede de inconstitucionalidade por omissão. Mas quando desfaz o que já havia sido realizado para cumprir essa tarefa e com isso atinge uma garantia de um direito fundamental, então a censura constitucional já se coloca no plano da própria inconstitucionalidade por acção. Se a Constituição impõe ao Estado a realização de uma determinada tarefa - a criação de uma instituição, uma alteração na ordem jurídica -, então, quando ela seja levada a cabo, o resultado passa a ter a protecção, direta da Constituição. $O$ Estado não pode voltar atrás, não pode descumprir o que cumpriu, não pode tornar a colocar-se na posição de devedor. É que aí a tarefa constitucional a que o Estado se acha obrigado é uma garantia do direito fundamental, constitui ela mesma objecto de um direito dos cidadãos [...]. As tarefas constitucionais impostas ao Estado em sede de direitos fundamentais no sentido de criar certas instituições ou serviços não o obrigam apenas a criá-los, obrigam-no também a não aboli-los uma vez criados. ${ }^{86}$

Ou seja, o Estado não pode voltar atrás, não pode descumprir o que cumpriu. Perceba-se o ano, 1984, antes mesmo da Constituição Federal de 1988 ter sido editada.

No mesmo sentido, comenta ainda José Joaquim Gomes Canotilho, "uma vez tendo contemplado um direito social, não pode eliminá-lo posteriormente retornando sobre os seus passos". Dito Acórdão, declarou, portanto inconstitucional o "DL no 245/82,

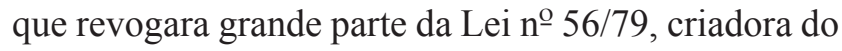
Serviço Nacional de Saúde" a partir do momento que o Estado cumpre (total ou parcialmente) as tarefas constitucionalmente impostas para realizar um direito social, o respeito constitucional deste deixa de consistir (ou deixa de consistir apenas) numa obrigação positiva, para se transformar ou passar também a ser uma obrigação negativa. O Estado, que estava obrigado a atuar para dar satisfação ao direito social, passa a estar obrigado a abster-se de atentar contra a realização dada ao direito social. ${ }^{87}$

Dessa forma, o Tribunal Constitucional português reconheceu a existência do princípio da proibição de retrocesso social, que declarou a inconstitucionalidade de lei infraconstitucional. ${ }^{88}$

Destaca Ingo Wolfgang Sarlet, outro Acórdão do Tribunal Português, (Acórdão no 509/2002, Processo no 768/2002, apreciado pelo Tribunal Constitucional de Portugal em 19.12.2002) cuja inconstitucionalidade por violação do princípio da proibição de retrocesso, pois excluiu da fruição do benefício às pessoas com idade entre 18 e 25 anos. Veja-se

\begin{abstract}
Decreto da Assembleia da República que, ao substituir o antigo rendimento mínimo garantido por um novo rendimento social de inserção, excluiu da fruição do benefício (ainda que mediante a ressalva dos direitos adquiridos) pessoas com idade entre 18 e 25 anos. Em termos gerais e para o que importa neste momento, a decisão, ainda que não unânime, entendeu que a legislação revogada, atinente ao rendimento mínimo garantido, concretizou o direito à segurança social dos cidadãos mais carentes (incluindo os jovens entre os 18 e 25 anos), de tal sorte que a nova legislação, ao excluir do novo rendimento social de inserção as pessoas nesta faixa etária, sem a previsão e/ou manutenção de algum tipo de proteção social similar, estaria a retroceder no grau de realização já alcançado do direito à segurança social a ponto de violar o conteúdo mínimo desse direito já que atingido o conteúdo nuclear do direito a um mínimo de existência condigna, não existindo outros instrumentos jurídicos que o possam assegurar com um mínimo de eficácia. ${ }^{89}$
\end{abstract}

Não é mais possível, nem plausível, retroceder ao grau de realização já alcançado anteriormente pela sociedade.

Ainda exemplificativamente, na Constituição Italiana, de 1947, as normas referentes aos direitos sociais foram chamadas "pudicamente de programáticas," adverte Norberto Bobbio: 
Será que já nos perguntamos alguma vez que gênero de normas são essas que não ordenam, proíbem ou permitem hit et nunc, mas ordenam, proíbem e permitem num futuro indefinido e sem um prazo de carência claramente delimitado? E, sobretudo, já nos perguntamos alguma vez que gênero de direitos são esses que tais normas definem? Um direito cujo reconhecimento e cuja efetiva proteção são adiados sine die, além de confiados à vontade de sujeitos cuja obrigação de executar o 'programa' é apenas uma obrigação moral ou, no máximo política, pode ainda ser chamado de direito? A diferença entre esses auto-intitulados direitos e os direitos propriamente ditos não será tão grande que torna impróprio ou, pelo menos, pouco útil o uso da mesma palavra para designar uns e outros?". ${ }^{90}$

Direitos sociais, não são meras normas programáticas, são, com base no princípio da vedação do retrocesso, concretizadoras de direitos, não pode ser entendido (pelo menos contemporaneamente) como obrigação moral, e sim pleno direito. E porque essa abordagem de âmbito internacional é importante, justamente para frisar, coadunar e aceitar que a proibição do retrocesso é um patamar obedecido pelos Estados internacionais (fixando eles mesmos as normas para o caso de inobservância).

Diga-se de passagem, que o direito à proibição de retrocesso social consiste em importante conquista civilizatória, como refere Dayse Coelho de Almeida:

O conteúdo impeditivo deste princípio torna possível brecar planos políticos que enfraqueçam os direitos fundamentais. Funciona até mesmo como forma de mensuração para o controle de inconstitucionalidade em abstrato, favorecendo e fortalecendo o arcabouço de assistência social do Estado e as organizações envolvidas no processo. [...] Em um país tão marcado pela desigualdade social como o Brasil, os impactos do processo de globalização econômica e as matizes neoliberais políticas fazem brotar no constitucionalismo contemporâneo a necessidade de elaborar formas de proteger os direitos sociais, em especial os trabalhistas, (aqui em especial acrescentaria também o direito a saúde) garantindo o mínimo necessário à dignidade da vida. ${ }^{91}$

Necessário transpassar da mera dogmática e alcançar a realidade, diria Dayse Coelho Nunes, é ir "além da análise do problema, propondo soluções palpáveis e de aplicabilidade imediata". Sendo que essa função social "urge ser incessantemente perseguida, sob pena de retrocessão na própria civilização". ${ }^{92}$
O princípio da proibição de retrocesso social está implicitamente inserido na Constituição Federal de $1988,{ }^{93}$ e, quando o sistema jurídico define certo direito como fundamental, esse não pode ser suprimido ou mesmo restringido de forma inadequada, capaz de causar retrocesso na sua utilização (ou atualização ${ }^{94}$ ), pois, a função protetora do princípio é servir de "limite" à atividade do intérprete e do legislador "impedindo-o de implementar mudanças interpretativas ou legislativas que determinem um retrocesso na área juridicamente protegida pelo direito fundamental em voga". ${ }^{95}$

Ainda e por fim exemplificando, a Quinta Câmara Cível do Tribunal de Justiça do Estado do Rio Grande do Sul, em Acórdão proferido nos autos da apelação cível no 598193845, de 17 de dezembro de 1998, de relatoria do Desembargador Carlos Alberto Bencke. Sendo que suscitou, pela primeira vez no Estado do Rio Grande do Sul, o princípio da proibição do retrocesso social para solucionar um caso concreto, traz Rodrigo Goldchmidt, de desconto de mensalidade para o segundo filho:

A questão controvertida, objeto da decisão em tela, girava em torno da aplicação do artigo 24 do Decreto-Lei 3.200/41, o qual prevê a concessão de descontos nas taxas escolares para aquelas famílias que possuem mais de um filho matriculado no mesmo estabelecimento de ensino. A tese levantada pelo apelante é a de que o referido dispositivo legal teria sido revogado pela legislação posterior e, além disso, não teria sido recepcionado pelas Constituições Federais que lhe sucederam, eis que estas mesmas passaram a contemplar as "famílias carentes" e não mais as "famílias numerosas", diferentemente do que fazia a Constituição Federal de 1937. O apelado, por seu turno, argumentou a plena vigência do artigo 24 do Decreto-Lei $3.200 / 41$, sustentando que este foi recepcionado pela Constituição Federal de 1988. O citado órgão julgador, sopesando os argumentos e os fundamentos aprestados pelas partes, acima resumidamente expostos, conferiu ganho de causa ao apelado". ${ }^{96}$

Finaliza o autor, que o princípio da proibição do retrocesso social, para além da "sua base normativoteórica, possui aplicabilidade prática, fundamentando a proteção e a defesa dos direitos fundamentais incorporados ao patrimônio jurídico do homem". Vez que, garante os direitos fundamentais contra a "atividade legislativa e hermenêutica corrosiva do catálogo de direitos fundamentais". ${ }^{97}$

No mesmo sentido aponta Ingo Wolfgang Sarlet, que o princípio em sentido amplo, já foi recepcionado no âmbito do constitucionalismo latino-americano. 
A aplicação da noção de proibição de retrocesso, desde que tomada em sentido amplo, no sentido de uma proteção dos direitos contra medidas de cunho restritivo, a todos os direitos fundamentais. Assim, verifica-se que a designação proibição de retrocesso social, que opera precisamente na esfera dos direitos sociais, especialmente no que diz com a proteção 'negativa' (vedação da supressão ou diminuição) de direitos a prestações sociais, além de uma ideia-força importante (a iluminar a ideia de que existe de fato um retrocesso - e não um simples voltar atrás, portanto, uma mera medida de cunho regressivo), poderia ser justificada a partir de algumas peculiaridades dos direitos sociais, o que, importa sempre frisar, não se revela incompatível com a substancial equivalência - de modo especial no que diz com sua relevância para a ordem constitucional - entre direitos sociais (positivos e negativos) e os demais direitos fundamentais. ${ }^{98}$

É tido, como norma ou piso hermenêutico para novas conquistas, devendo "regular qualquer processo de reforma da constituição" ${ }^{99}$ E atua como "baliza para a impugnação de medidas que impliquem supressão ou restrição de direitos sociais". ${ }^{100}$

Ao passo em que se chega a uma proibição apenas relativa de retrocesso, ${ }^{101}$ sendo que tal proteção não pode assumir um caráter absoluto, "notadamente no que diz com a concretização dos direitos sociais a prestações", aponta Ingo Wolfgang Sarlet:

pode-se partilhar do entendimento de que entre uma negativa total da eficácia jurídica do princípio da proibição de retrocesso (que, ao fim e ao cabo, teria a função de mera diretriz para os agentes políticos) e o outro extremo, o que propugna uma vedação categórica de todo e qualquer ajuste em termos de direitos sociais, também aqui o melhor caminho é o do meio, ou seja, o que implica uma tutela efetiva, mas não cega e descontextualizada dos direitos fundamentais sociais. ${ }^{102}$

Em conclusão adverte Fahd Medeiros Awad, sem atingir o mínimo essencial, não há que se falar em retrocesso, pois a proibição de um retrocesso visa a almejada evolução da sociedade, ${ }^{103}$ é um limite às limitações:

A proibição de retrocesso seria um específico limite às limitações ou restrições legislativas a direito fundamental, impedindo que um direito fundamental já regulamentado sofra alterações que reduzam o significado que lhe foi atribuído pela norma anterior ordinária ou constitucional. Nesse sentido, reconhece-se o poder de conformação do legislador no mister de quantificar e formatar os direitos fundamentais, autorizando lhes, inclusive, uma diminuição das posições jurídicas alcançadas, desde que a norma não aniquile o direito atingindo o seu mínimo existencial. Sem atingir esse mínimo, não há retrocesso, mas mera diminuição em quantidade. Afetado o essencial, a norma será maculada pela inconstitucionalidade, pois derrogou o cerne que caracteriza os direitos fundamentais. ${ }^{104}$

Endossa-se que o reconhecimento de direitos originários a prestações, que consiste na "possibilidade de - a partir da norma constitucional e independentemente de qualquer mediação legislativa - reconhecer-se um direito subjetivo à prestação"105. É fundamental para que o próprio direito a saúde reste amparado, assegurado e também concretizado.

Fica claro, a não aceitação da predominância dos direitos de defesa sobre os direitos de prestação, pois todos os direitos são importantes, é o que oportuniza Emilio Garcia Mendez:

[...] mediante a afirmação de que todos os direitos são igualmente prioritários, tem provocado, principalmente nos países do Sul, um aumento nas violações aos direitos políticos, ao mesmo tempo em que não tem provocado qualquer avanço significativo no campo dos direitos econômicos e sociais. Considerando o caráter político e culturalmente hegemônico que assumiu a dimensão dos direitos humanos que mais adiante caracterizarei como 'programático', estabelecer que todos os direitos são igualmente importantes e, em conseqüência, igualmente prioritários, constitui uma forma sutil de confirmar a prioridade real daqueles direitos cujo não cumprimento não chega a gerar fortes tensões políticas com os Estados. A possibilidade de estabelecer um relacionamento de constante cooperação não-conflitante com o Estado, se a prioridade real são os direitos econômicos e sociais, explica, em boa medida, o caráter hegemônico dessa tendência. ${ }^{106}$

Os direitos de prestação não podem ser concretizados sem a efetiva intervenção do Estado, pois, não faz sentido algum em priorizar alguns direitos em detrimento de outros, pela singela razão de que os direitos fundamentais são unos, ou seja, são indivisíveis, sendo que "esta ideia de indivisibilidade implica que os direitos do homem formem um todo e que não se possa estabelecer uma hierarquia entre eles", ${ }^{107}$ vez que, viria de encontro (direitos de defesa sobre os direitos de prestação) que contraria a indivisibilidade 
dos direitos fundamentais, argumento Marcos Cesar Santos Vasconcelos: "Não se pode deixar que os direitos fundamentais de prestação sejam relegados à caridade, isto porque são direitos assegurados constitucionalmente e é dever do Estado garanti-los", ${ }^{108}$ justamente porque os direitos às prestações, cunho positivo, são tão fundamentais quanto os direitos de defesa, cunho negativo. E isso, pode se perceber especificamente no direito fundamental social à saúde.

Por tudo, está vedada a proibição de retrocesso em nível nacional-constitucional, assim como o dever de progressão em nível internacional, pois são duas dimensões intimamente ligadas e que demandam efetivação.

\section{CONCLUSÃO}

A abordagem dos direitos sociais é de fundamental importância, exarados no artigo $6^{\mathrm{o}}$ da Constituição Federal de 1988, mudou uma concepção legislativa, pois são hoje, tanto prestacionais (portanto positivos) como defensivos (portanto negativos), em prol da dupla fundamentalidade desses na ordem constitucional nacional.

Interpretando-se o espírito do legislador, verificase a intenção de que os direitos fundamentais não ficassem limitados aos expressamente previstos no texto constitucional, mas que houvesse um processo contínuo de extensão, de amplitude desses direitos. Sendo que a implementação de políticas públicas faz com que a população tenha nas suas expectativas, uma promessa de concretização dos direitos sociais, vez que atribuição do Estado, e, que deve assumir o seu dever-função, o seu papel.

Deixar de concretizar os direitos é retroceder no tempo, vez que, a proibição de retrocesso social guarda estreita relação com a proteção e promoção dos direitos sociais em âmbito interno, guarda relação também com o dever de progressiva realização, em âmbito internacional, contido em cláusulas vinculativas de Direito Internacional priorização do dever de implantação efetiva, a exemplo do (Pacto Internacional de direitos sociais, econômicos e culturais, de 1966; Protocolo de San Salvador; Convenção Americana de Direitos Humanos de 1969) de uma inclusão cidadã.

Ou seja, a menção expressa a esse princípio de não poder retroceder sem que isso signifique violar frontalmente a Constituição de 1988, representou um grande marco, acolhido pela doutrina e jurisprudência brasileira, mesmo não tendo sido expressamente acolhido pelas constituições latino-americanas representa no contexto atual o acolhimento e consagração em âmbito nacional e internacional, portanto, o princípio da proibição do retrocesso impede, em tema de direitos fundamentais de caráter social, que sejam desconstituídas as conquistas já alcançadas pela população.

\section{REFERÊNCIAS}

AFONSO, Túlio Augusto Tayano. Direitos sociais e princípio do não retrocesso social. Revista de Direito do Trabalho, ano 32, n. 124. p. 237-252, out.-dez. 2006.

ALEXY, Robert. Sistema jurídico, princípios jurídicos y razón práctica. Doxa - Cuadernos de Filosofia del Derecho, n. 5, p. 139151, 1988. Disponível em: <http://www.cervantesvirtual.com/ servlet/SirveObras? portal $=0 \&$ urlPropia $=15290>$. Acesso em: 04 fev. 2013.

ALMEIDA, Dayse Coelho de. A fundamentalidade dos direitos sociais e o princípio da proibição de retrocesso. Inclusão Social, Brasília, v. 2, n. 1, p. 118-124, out. 2006-mar. 2007.

ALMEIDA, Rosângela da Silveira. Proteção social no Mercosul: a saúde dos trabalhadores de municípios fronteiriços do Rio Grande do Sul. Porto Alegre, 2008. Tese (Doutorado em Serviço Social) - Faculdade de Serviço Social, PUCRS. Orientação: Profa. Dra. Jussara M. R. Mendes.

AMAPÁ, Supremo Tribunal Federal. Are 639337 Agr, Relator(a): Min. Celso De Mello, Segunda Turma, julgado em 23/08/2011, dje-177 divulg 14-09-2011 public 15-09-2011 ement vol-0258701 PP-00125. Disponível em: <http://www.stf.jus.br/portal/ jurisprudencia/listarJurisprudencia.asp?s $1=\% 28 \mathrm{sa} \%$ FAde + reser va + do + poss $\%$ EDvel $\% 29 \&$ base $=$ baseAcordaos $>$. Acesso em: 05 abr. 2013.

ATIENZA, Manuel. Entrevista com Robert Alexy. Doxa-Publi caciones periódicas. n. 24, 2001. Disponível em: <http://www. cervantesvirtual.com/servlet/SirveObras/013727197680288374 22802/doxa24/doxa24 28.pdf>. Acesso em: 25 jan. 2010.

ATRIA, Fernando. Existem direitos sociais? In: MELLO, Cláudio Ari (Coord.). Os desafios dos direitos sociais. Porto Alegre: Livraria do Advogado, 2005.

AWAD, Fahd Medeiros. Proibição de retrocesso social diante da garantia do núcleo essencial dos direitos fundamentais. Revista Justiça do Direito, v. 24, n. 1, p. 90-100, 2010. Disponível em: $<$ http://www.upf.br/seer/index.php/rjd/article/view/2146>. Acesso em: 11 abr. 2013.

BARCELLOS, Ana Paula de. A eficácia jurídica dos princípios constitucionais: o princípio da dignidade da pessoa humana. Rio de Janeiro: Renovar, 2002.

BARNES, Javier. Introducción al principio de proporcionalidad en el derecho comparado y comunitario. Revista de Administración Pública, Madrid, n. 135, p. 495-522, 1994.

BARRETO, Vicente de Paulo. Reflexões sobre os direitos sociais. In: SARLET, Ingo Wolfgang (Org.). Direitos fundamentais sociais: estudos de Direito Constitucional, Internacional e comparado. Rio de Janeiro: Renovar, 2003.

BARROSO, Luís Roberto. O direito constitucional e a efetividade de suas normas. 5. ed. Rio de Janeiro: Renovar, 2001 e 2006.

BOBBIO, Norberto. Era dos direitos. Rio de Janeiro: Campus, 1992. BOVEN, Theodoor C. van. Os critérios de distinção dos direitos do homem. In: VASAK, Karel. As dimensões internacionais dos direitos do homem. Tradução de Carlos Alberto Aboim de Brito. Lisboa: Editora Portuguesa de Livros Técnicos e Científicos, 1983. BRASILIA, Supremo Tribunal Federal, ADI nº 2065-0/DF, voto do Ministro Sepúlveda Pertence. Disponível em: <http://redir.stf. jus.br/paginadorpub/paginador.jsp? $\mathrm{doc} T \mathrm{P}=\mathrm{AC} \& \operatorname{doc} \mathrm{ID}=375320>$. Acesso em: 17 abr. 2013. 
BRASILIA, Supremo Tribunal Federal, ADI no 2065-0/DF, voto do Ministro Sepúlveda Pertence. Disponível em: $<$ http://redir.stf. jus.br/paginadorpub/paginador.jsp? docTP $=\mathrm{AC} \& \operatorname{doc} \mathrm{ID}=375320>$. Acesso em: 17 abr. 2013.

BRAVO, Maria Inês Souza. Política de Saúde no Brasil. In: BRAVO, Maria Inês Souza et al. (Orgs.). Serviço Social e saúde: formação e trabalho profissional. Brasília: ABEPSS, 2006.

BUCCI, Maria Paula Dallari. Direito Administrativo e politicas públicas. São Paulo: Saraiva, 2002.

BÜHRING, Marcia Andrea. Direitos humanos e fundamentais, migração nas fronteiras Brasil e Uruguai: uma análise dos déficits do direito social à saúde da mulher nas cidades gêmeas: Santana do Livramento-BR/Rivera-UR e Chuí-BR/Chuy-UR. Tese (Doutorado) - Programa de Pós-Graduação em Direito da Faculdade de Direito da Pontifícia Universidade Católica do Rio Grande do Sul, Porto Alegre, 2013.

CANOTILHO, José Joaquim Gomes. Direito Constitucional. Coimbra: Almedina, 2003.

CANOTILHO, Joaquim José Gomes. Direito Constitucional e teoria da constituição. 3. ed. Coimbra: Almedina, 1998; 7.ed. 2003.

CANOTILHO, José Joaquim Gomes. Estudos sobre direitos fundamentais. Coimbra: Coimbra Editora, 2004.

CANOTILHO, José Joaquim Gomes; MOREIRA, Vital. Fundamentos da constituição. Coimbra: Coimbra Ed., 1991.

DERBLI, Felipe. O princípio da proibição de retrocesso social na Constituição de 1988. São Paulo: Renovar, 2007.

DIMOULIS, Dimitri; MARTINS, Leonardo. Teoria geral dos direitos fundamentais. 3. ed. rev., atual. e ampl. São Paulo: Revista dos Tribunais, 2011.

DINIZ, Maria Helena. Dicionário jurídico. São Paulo: Saraiva, 1998. v. 3.

DWORKIN, Ronald. Levando os direitos a sério. Tradução de Nelson Boeira. São Paulo: Martins Fontes, 2002.

FARIA, José Eduardo (Org.). O Judiciário e os direitos humanos e sociais: notas para uma avaliação da justiça brasileira. In: FARIA, José Eduardo (Org.). Direitos humanos, direitos sociais e justiça. São Paulo: Malheiros, 1994.

FERRARI, Regina Maria Macedo Nery. Necessidade de Regulamentação Constitucional. In: Caderno de Direito Constitucional e Ciência Política, v. 18, Ed. Revista dos Tribunais.

FILETI, Narbal Antônio Mendonça. O princípio da proibição de retrocesso social. Breves considerações. Jus Navigandi, Teresina, ano 14, n. 2059, 19 fev. 2009. Disponível em: <http://jus.com.br/ revista/texto/12359>. Acesso em: 9 abr. 2013.

GOLDSCHMIDT, Rodrigo. O princípio da proibição do retrocesso social e sua função protetora dos direitos fundamentais. Disponível em <http://editora.unoesc.edu.br/index.php/seminarionacional dedimensoes/article/view/906/521>. Acesso em: 11 abr. 2013.

HÄBERLE, Peter. Dignita Dell'Uomo e Diritti Sociali nelle Costituzioni degli Stati di Diritto. In: Costituzione e Diritti Sociali. Éditions Universitaires Fribourg Suisse, 1990.

LEAL, Roger Stiefelmann. Direitos sociais e a vulgarização da noção de direitos fundamentais. Disponível em: <http://www6. ufrgs.br/ppgd/doutrina/leal2.htm>. 2008. Acesso em: 8 abr. 2013.

LIMA, George Marmelstein. Críticas à teoria das gerações (ou mesmo dimensões) dos direitos fundamentais. Jus Navigandi, Teresina, ano 8, n. 173, 26 dez. 2003. Disponível em: <http://jus. com.br/revista/texto/4666>. Acesso em: 4 mar. 2013.

MACIEL. Álvaro dos Santos. Do princípio do não-retrocesso social. Disponível em <http://www.boletimjuridico.com.br/ doutrina/texto.asp?id=1926>. Acesso em: 10 abr. 2013.

MÉNDEZ, Emílio Garcia. Origem, sentido e futuro dos direitos humanos: reflexões para uma nova agenda. Revista Internacional de Direitos Humanos, Rede Universitária de Direitos Humanos SUR, ano 1, n. 1, 1ํㅗ. 2004.

MENDES, Gilmar Ferreira. Direitos fundamentais e controle de constitucionalidade. 3. ed. São Paulo: Saraiva, 2004.

MIRANDA. Jorge. Manual de Direito Constitucional. Coimbra: Coimbra, 1990 e 2000.

MOLINARO, Carlos Alberto. Direito Ambiental: proibição de retrocesso. Porto Alegre: Livraria do Advogado, 2007.

MOLINARO, Carlos Alberto. Racionalidade Ecológica e Estado Socioambiental e Democrático de Direito. Dissertação (Mestrado) - Programa de Pós-Graduação em Direito da Faculdade de Direito da Pontifícia Universidade Católica do Rio Grande do Sul, 2006.

PEREIRA, I. S. S. D. Promoção da saúde: algumas notas. Revista Desafios Sociais. Natal, n. 2, p. 126-139, jan.-jul. 2002.

PIOVESAN, Flávia. Direitos econômicos, sociais e culturais e os desafios. Revista Consultor Jurídico, 2002. Disponível em: <http:// conjur.estadao.com.br/static/text/10798,1>. Acesso em: 9 abr. 2013.

PIOVESAN, Flávia. Direitos humanos e o direito constitucional internacional. 4. ed. São Paulo: Max Limonad, 2000.

PIOVESAN, Flávia. Não à desconstitucionalização dos direitos sociais. Revista Consultor Jurídico, 02 de jun. 2000. Disponível em: <http://conjur.uol.com.br/textos/2843/>. Acesso em: 10 abr. 2013.

QUEIROZ, Cristina M. M. O Principio da não reversibilidade dos direitos fundamentais sociais. Coimbra: Coimbra Ed., 2007.

RAICHELIS, Raquel. Gestão pública e a questão social na grande cidade. Lua Nova, São Paulo, n. 69, p. 13-48, 2006. Disponível em: <http://www.scielo.br/pdf/ln/n69/a03n69.pdf $>$. Acesso em: 15 ago. 2010.

REALE, Miguel. $O$ direito como experiência: introdução à epistemologia jurídica. 2. ed. São Paulo: Saraiva, 1992.

SILVA, Jorge Pereira da. Dever de legislar e protecção jurisdicional contra omissões legislativas: contributo para uma teoria da inconstitucionalidade por omissão. Lisboa: Universidade Católica, 2003.

SILVA, José Afonso da. Curso de Direito Constitucional Positivo. 34. ed. rev e atual. São Paulo: Malheiros, 2011.

SARLET, Ingo Wolfgang. A eficácia dos direitos fundamentais. 10. ed. rev., atual. e ampl. Porto Alegre: Livraria do Advogado, 2011.

SARLET, Ingo Wolfgang. A eficácia do direito fundamental à segurança jurídica: dignidade da pessoa humana, direitos fundamentais e proibição de retrocesso social no direito constitucional brasileiro. 2005. Disponível em: <http://www. mundojuridico.adv.br>. Acesso em: 09 abr. 2013.

SARLET. Ingo Wolfgang. Notas sobre a assim designada proibição de retrocesso social no constitucionalismo Latino-americano. Rev. TST, Brasília, v. 75, n. 3, jul.-set. 2009. p. 117. Disponível em $<$ http://www.tst.jus.br/documents/1295387/1312882/7.+notas+so bre $+\mathrm{a}+$ assim + designada + proibi $\%$ c 3\%a $7 \% \mathrm{c} 3 \% \mathrm{a} 3 \mathrm{o}+\mathrm{de}+$ retrocess $\mathrm{o}+$ social + no + constitucionalismo+latino-americano $>$. Acesso em: 10 abr. 2013.

SARLET, Ingo Wolfgang. Os direitos sociais como direitos fundamentais: contributo para um balanço aos vinte anos da Constituição Federal de 1988. Revista do Instituto de Hermenêutica Jurídica, 20 Anos de Constitucionalismo Democrático - E Agora? Porto Alegre-Belo Horizonte, 2008.

SARLET, Ingo Wolfgang; FIGUEIREDO, Mariana Fichtner. Reserva do possível, mínimo existencial e direito à saúde: algumas aproximações. Direitos Fundamentais \& Justiça, Porto Alegre, ano 1, n. 1. p. 177-178, out.-dez. 2007.

STRECK, Lênio Luiz. Hermenêutica jurídica e $(m)$ crise: uma exploração hermenêutica da construção do Direito. 4. ed. rev. atual. Porto Alegre: Livraria do Advogado, 1999 e 2003. 
STRECK, Lenio Luiz. Jurisdição constitucional e hermenêutica: Uma nova crítica do direito. 2. ed. Rio de Janeiro: Forense, 2004.

TAVARES, André Ramos. Curso de direito constitucional. 7. ed. São Paulo: Saraiva, 2009.

TORRES, Ricardo Lobo. O direito ao mínimo existencial. Rio de Janeiro: Renovar, 2009.
VASCONCELOS, Marcos Cesar Santos. As decisões normativas na jurisdição constitucional. Dissertação (Mestrado) Instituto Brasiliense de Direito Público - IDP, Brasília, 2010.

WEIS, Carlos. Direitos humanos contemporâneos. São Paulo: Malheiros, 2006.

\section{NOTAS}

1 BARRETO, Vicente de Paulo. Reflexões sobre os direitos sociais. In: SARLET, Ingo Wolfgang (org.). Direitos fundamentais sociais: estudos de Direito Constitucional, Internacional e Comparado. Rio de Janeiro: Renovar, 2003. p.129.

2 BARRETO, Vicente de Paulo. Reflexões sobre os direitos sociais. In: SARLET, Ingo Wolfgang (org.). Direitos fundamentais sociais: estudos de Direito Constitucional, Internacional e Comparado. Rio de Janeiro: Renovar, 2003. p.129.

3 Refere: "Quando, porém, se fala na 'estrutura tridimensional do direito', neste conceito já está implícita a nota essencial da temporalidade, pois é inconcebível uma estrutura social estática, desvinculada do processo histórico: o direito, como a realidade social toda da qual participa, é, fundamentalmente, uma estrutura tridimensional e histórica, distinguindo-se das demais por possuir uma nota específica, que é a bilateralidade atributiva inerente a todas as formas de ordenação jurídica da conduta humana. Essas três características essenciais de tridimensionalidade, temporalidade e bilateralidade-atributiva, penso estarem sintetizadas quando conceituo o Direito como realidade histórica-cultural tridimensional de natureza bilateral atributiva". [...] "Na realidade, os três aspectos ora examinados reduzem-se a uma questão única: à da temporalidade do direito, quer se focalize um modelo jurídico particular, quer se estude a totalidade do ordenamento, pois, as relações sociais só são jurídicas enquanto processo histórico ordenado segundo valores realizáveis em termos de intersubjetividade ou de bilateralidade atributiva. No mundo do direito, de certo ponto de vista, tudo é história: o erro consiste em absolutizar esse ponto de vista, confundindo-se o direito histórico com todo o direito, esquecendo-se, assim, que o fato histórico não teria significado se não houvesse sempre história por fazer" $[\ldots]$ REALE, Miguel. O direito como experiência: introdução à epistemologia jurídica. 2. ed. São Paulo: Saraiva, 1992. p. 218-222.

4 Veja-se: "Os direitos sociais, como dimensão dos direitos fundamentais do homem, são prestações positivas proporcionadas pelo Estado, direta ou indiretamente, enunciadas em normas constitucionais, que possibilitam melhores condições de vida aos mais fracos, direitos que tendem a realizar a igualização de situações sociais desiguais. São, portanto, direitos que se ligam ao direito de igualdade". SILVA, José Afonso da. Curso de Direito Constitucional Positivo. 34. ed. rev e atual. São Paulo: Malheiros Editores, 2011. p. 286-287.

5 SARLET, Ingo Wolfgang. A eficácia dos Direitos Fundamentais. 10. ed. rev., atual. e ampl. Porto Alegre: Livraria do Advogado, 2011. p. 281-282.

6 CANOTILHO, José Joaquim Gomes. Direito Constitucional e Teoria da Constituição. 7. ed. Portugal - Coimbra: Almedina, 2003. p. 477.

7 CANOTILHO, José Joaquim Gomes e MOREIRA, Vital. Fundamentos da Constituição. Coimbra: Coimbra, 1991. p. 131.

8 SARLET, Ingo Wolfgang. A eficácia dos Direitos Fundamentais. 10. ed. rev., atual. e ampl. Porto Alegre: Livraria do Advogado, 2011. p. 187198.

9 DIMOULIS, Dimitri; MARTINS, Leonardo. Teoria Geral dos Direitos Fundamentais. 3. ed. rev., atual. e ampl. São Paulo: Revista dos Tribunais, 2011. p. 60-61.

${ }_{10}$ Observe-se: "Essa falsa distinção, repetida sem muito questionamento por quase todos os juristas, é a responsável pela principal crítica que pode ser feita à teoria das gerações dos direitos fundamentais, já que enfraquece bastante a normatividade dos direitos sociais, retirando do Poder Judiciário a oportunidade de efetivar esses direitos. É um grande erro pensar que os direitos de liberdade são, em todos os casos, direitos negativos, e que os direitos sociais e econômicos sempre exigem gastos públicos. Na verdade, todos os direitos fundamentais possuem uma enorme afinidade estrutural. Concretizar qualquer direito fundamental somente é possível mediante a adoção de um espectro amplo de obrigações públicas e privadas, que se interagem e se complementam, e não apenas com um mero agir ou não agir por parte do Estado. [...] Por isso, é fundamental que se afaste essa equivocada dicotomia de que os direitos de liberdade são direitos negativos, não onerosos, e que os direitos sociais são direitos a prestações, onerosos." George Marmelstein Lima afirma: "Essa falsa divisão afeta diretamente a teoria da aplicabilidade das normas constitucionais, contribuindo para reforçar a odiosa tese de que os direitos sociais são meras normas programáticas, cuja aplicação ficaria a depender da boa vontade do legislador e do administrador público, não podendo a concretização desses direitos ser exigida judicialmente". LIMA, George Marmelstein. Críticas à teoria das gerações (ou mesmo dimensões) dos direitos fundamentais. Jus Navigandi, Teresina, ano 8, n. 173, 26 dez. 2003. Disponível em: <http:// jus.com.br/revista/texto/4666>. Acesso em: 4 mar. 2013.

11 LIMA, George Marmelstein. Críticas à teoria das gerações (ou mesmo dimensões) dos direitos fundamentais. Jus Navigandi, Teresina, ano 8, n. 173, 26 dez. 2003. Disponível em: <http://jus.com.br/revista/ texto/4666>. Acesso em: 4 mar. 2013.

${ }_{12}$ Afirma: "Revestem eles, na Constituição, a forma de princípios de justiça, de normas programáticas ou de policy, sujeitos sempre à interpositio legislatoris, especificamente na via do orçamento público, que é o documento de quantificação dos valores éticos, a conta corrente da ponderação dos princípios constitucionais, o plano contábil da justiça social, o balanço das escolhas dramáticas por políticas públicas em um universo fechado de recursos financeiros escassos e limitados". TORRES, Ricardo Lobo. O direito ao mínimo existencial. Rio de Janeiro: Renovar, 2009. p.273.

13 ALMEIDA, Dayse Coelho de. A fundamentalidade dos direitos sociais e o princípio da proibição de retrocesso. Inclusão Social, Brasília, v. 2, n.1. p.118-124, out. 2006/ mar. 2007. p.118

14 “Com isto não se está a dizer - é bom enfatizar - que os níveis de proteção social, concretizados pela via da legislação ordinária e das políticas públicas, não sejam em vários casos até mesmo mais altos do que em países onde a opção foi pela constitucionalização dos direitos sociais, o que, por sua vez, acaba, para alguns, servido de argumento adicional para justificar não apenas a desnecessidade e mesmo inconveniência da inserção de direitos sociais nas constituições. Da mesma forma, segue acesa a controvérsia na esfera doutrinária e jurisprudência, seja no que diz respeito à própria fundamentação e legitimação dos direitos sociais, seja no que concerne ao seu conteúdo e regime jurídico. Assim, resulta evidente que mesmo à vista da expressa previsão de direitos sociais no catálogo constitucional dos direitos fundamentais, também entre nós tais temas têm sido objeto de crescente e cada vez mais intenso (em termos quantitativos e qualitativos) debate". SARLET, Ingo Wolfgang. Os Direitos Sociais como Direitos Fundamentais: contributo para um balanço aos vinte anos da Constituição Federal de 1988. Revista do Instituto de Hermenêutica Jurídica. 20 Anos de Constitucionalismo Democrático - E Agora? Porto Alegre-Belo Horizonte, 2008. p.163-206.

${ }^{15}$ ATRIA, Fernando. "Existem Direitos Sociais?" in: MELLO, Cláudio Ari (Coord.). Os Desafios dos Direitos Sociais. Porto Alegre: Livraria do Advogado, 2005. p.09-46.

${ }^{16}$ Aduz: "partindo-se aqui do critério da natureza da posição jurídicosubjetiva reconhecida ao titular do direito, bem como da circunstância de que os direitos negativos (notadamente os direitos de não-intervenção na liberdade pessoal e nos bens fundamentais tutelados pela Constituição) apresentam uma dimensão "positiva" (já que sua efetivação reclama uma atuação positiva do Estado e da sociedade) ao passo que os direitos a prestações (positivos) fundamentam também posições subjetivas "negativas", notadamente quando se cuida de sua proteção contra ingerências indevidas por parte dos órgãos estatais, mas também por parte de organizações sociais e de particulares". SARLET, Ingo Wolfgang. Os Direitos Sociais como Direitos Fundamentais: contributo para um balanço aos vinte anos da Constituição Federal de 1988. Revista do Instituto de Hermenêutica Jurídica. 20 Anos de Constitucionalismo Democrático - E Agora? Porto Alegre-Belo Horizonte, 2008. p.163-206. 
${ }^{17}$ SARLET, Ingo Wolfgang. Os Direitos Sociais como Direitos Fundamentais: contributo para um balanço aos vinte anos da Constituição Federal de 1988. Revista do Instituto de Hermenêutica Jurídica. 20 Anos de Constitucionalismo Democrático - E Agora? Porto Alegre-Belo Horizonte, 2008. p.163-206.

18 Veja-se: "Em síntese, firma-se aqui posição em torno da tese de que - pelo menos no âmbito do sistema de direito constitucional positivo nacional - todos os direitos, tenham sido eles expressa ou implicitamente positivados, estejam eles sediados no Título II da CF (dos direitos e garantias fundamentais), estejam localizados em outras partes do texto constitucional ou nos tratados internacionais regularmente firmados e incorporados pelo Brasil, são direitos fundamentais. Como corolário desta decisão em prol da fundamentalidade dos direitos sociais na ordem constitucional brasileira, e por mais que se possa, e, até mesmo (a depender das circunstâncias e a partir de uma exegese sistemática, por mais que seja possível reconhecer eventuais diferenças de tratamento, os direitos sociais - por serem fundamentais -), comungam do regime da dupla fundamentalidade (formal e material) dos direitos fundamentais". SARLET, Ingo Wolfgang. Os Direitos Sociais como Direitos Fundamentais: contributo para um balanço aos vinte anos da Constituição Federal de 1988. Revista do Instituto de Hermenêutica Jurídica. 20 Anos de Constitucionalismo Democrático - E Agora? Porto Alegre-Belo Horizonte, 2008. p. 163-206.

19 FARIA, José Eduardo (Org.). O Judiciário e os direitos humanos e sociais: notas para uma avaliação da justiça brasileira. In: FARIA, José Eduardo. (Org.). Direitos humanos, direitos sociais e justiça. São Paulo: Malheiros, 1994. p. 105.

${ }^{20}$ PEREIRA, I. S. S. D. Promoção da saúde: algumas notas. Revista Desafios Sociais. Natal, n. 2. p. 126-139, jan.-jul. 2002. p. 152.

${ }^{21}$ BRAVO, Maria Inês Souza. Política de Saúde no Brasil. In: BRAVO, Maria Inês Souza et al. (Orgs.). Serviço Social e saúde: formação e trabalho profissional. Brasília: ABEPSS, 2006. p. 96-97.

${ }^{22}$ Numerus clausus, vem de clausura, vem de fechado, são números restritos.

23 TAVARES, André Ramos. Curso de direito constitucional. 7.ed. São Paulo: Saraiva, 2009. p. 799-800.

${ }^{24} \mathrm{O}$ autor traz Peter Häberle. In: Costituzione e Diritti Sociali, cit. p.99. E que se utiliza aqui também de forma exemplificativa. "Dentre as constituições latino-americanas que contemplam cláusulas de abertura a outros direitos (embora não especificamente em matéria de direitos sociais), citam-se, em caráter exemplificativo: Constituição da Nação Argentina de 1853 (amplamente reformada em 1994): art. 33; Constituição Política do Estado da Bolívia de 2009: art. 13, II; Constituição Política da República do Chile de 1980 (com a reforma de 2005): art. 5ㅜ; Constituição Política da Colômbia de 1991 (com a reforma de 2005): art. 94; Constituição Política da República da Guatemala de 1985 (com a reforma de 1993): art. 44; Constituição Política da República da Nicarágua de 1987 (com a reforma de 2007): art. 46; Constituição Política do Paraguai de1 992: art. 45; Constituição Política do Peru de 1993 (com a reforma de 2005): art. 3-; Constituição da República do Uruguai de 1967 (com as reformas até 1996): art. 6ㅜㅜㄹ Constituição da República Bolivariana da Venezuela de 1999: art. 22 Importante sinalar que a Constituição da República Federativa do Brasil, de 1988, além de uma cláusula geral de abertura a outros direitos (art. $5^{\mathrm{o}}, \S 2^{\mathrm{o}}$ ), refere expressamente uma abertura a outros direitos dos trabalhadores (art. 7ㅇ, caput)". SARLET. Ingo Wolfgang. Notas sobre a assim designada proibição de retrocesso social no constitucionalismo Latino-americano. Rev. TST, Brasília, v. 75, n. 3, jul.-set. 2009. p. 117. Disponível em <http://www.tst.jus.br/ documents/1295387/1312882/7 .+notas+sobre+a+assim+designada+pr oibi $\%$ c $3 \%$ a $7 \%$ c3\%a3o+de+retrocesso + social + no + constitucionalismo + latino-americano>. Acesso em: 10 abr. 2013.

${ }^{25}$ Exemplificativamente, no ordenamento jurídico brasileiro, o direito à saúde é, para a maioria dos juristas, um direito fundamental, porém, na Espanha (Constituição Espanhola de 1978), a situação é diferente, pois o direito à saúde não tem o mesmo tratamento dos direitos fundamentais". SARLET, Ingo Wolfgang. A eficácia dos Direitos Fundamentais. 10. ed. rev., atual. e ampl. Porto Alegre: Livraria do Advogado., 2011. p. 76-77.

26 Ingo Wolfgang Sarlet aduz em defesa da fundamentalidade dos direitos sociais: "que, embora existam possíveis distinções de tratamento, este fato não afasta a elevação dos direitos sociais à categoria de fundamentais, pois se sujeitam à lógica do art. $5^{\circ}, \S^{\circ} \stackrel{\circ}{ }$, da $\mathrm{CF}$, no significado de que, por serem imediatamente aplicáveis todas as normas de direitos fundamentais, deverá ser buscada a máxima eficácia e efetividade possível, inclusive no tocante aos direitos sociais, com a ressalva de que é evidente que a eficácia e efetividade irão variar conforme o direito em questão, pois as circunstâncias do caso concreto são fatores determinantes. Na medida em que certos valores são tidos como universais, como a vida e a dignidade da pessoa humana, mesmo que fiquem sujeitos à realidade fática, para que se verifique sua concretização, não pode ser afastada sua característica de fundamentalidade. Neste contexto, a ligação entre direitos fundamentais sociais, vida e dignidade da pessoa humana, que se traduzem em necessidades existenciais de qualquer indivíduo, [...].'” SARLET, Ingo Wolfgang. FIGUEIREDO, Mariana Filchtiner Reserva do possível, mínimo existencial e direito à saúde: algumas aproximações. Direitos Fundamentais \& Justiça, Porto Alegre, ano 1, n. 1, p. 177-178, out.-dez. 2007 - trimestral.

27 SARLET, Ingo Wolfgang. FIGUEIREDO, Mariana Filchtiner Reserva do possível, mínimo existencial e direito à saúde: algumas aproximações. Direitos Fundamentais \& Justiça, Porto Alegre, ano 1, n. 1, p. 177-178, out.-dez. 2007 - trimestral.

28 SARLET, Ingo Wolfgang. A eficácia dos direitos fundamentais. 10. ed. rev., atual. e ampl. Porto Alegre: Livraria do Advogado, 2011. p. 82-83.

${ }^{29}$ MIRANDA. Jorge. Manual de Direito Constitucional. Coimbra: Coimbra, 2000. p. 8.

${ }^{30}$ Há quem considere direitos sociais como meras normas programáticas. (mas não são). A exemplo de Roger Stiefelmann Leal que refere: "A inexistência, em termos práticos, de tutela judicial aos direitos sociais coloca-os em confronto com a própria idéia de direito fundamental. Afirma Loewenstein que os direitos sociais não são direitos em sentido estrito, já que não podem ser exigidos judicialmente do Estado antes de terem sido institucionalizados por uma ação estatal. Impõe-se, desta forma, o preceito inscrito no art. 75 do Código Civil de que para todo direito há uma ação correspondente que o garante. Não se está pretendendo interpretar a Constituição a partir de uma lei infra-constitucional - o que seria a priori incorreto - mas extrair a lógica intrínseca desse enunciado normativo. Ora, não há de se falar em direito se não há como assegurá-lo judicialmente, pois qualquer violação a este suposto direito não poderia ser, desde logo, sancionada ou compensada. A previsão de determinados reclamos da sociedade como direitos sociais acaba por tentar transformar metas, objetivos a serem atingidos em direitos fundamentais sem atentar para os seus elementos conceituais. Não há como qualificar objetivos como direitos, são conceitos estruturalmente incompatíveis". LEAL, Roger Stiefelmann. Direitos sociais e a vulgarização da noção de direitos fundamentais. Disponível em: <http://www6.ufrgs.br/ppgd/ doutrina/leal2.htm>. 2008. Acesso em: 8 abr. 2013.

31 ALMEIDA, Dayse Coelho de. A fundamentalidade dos direitos sociais e o princípio da proibição de retrocesso. Inclusão Social, Brasília, v. 2, n. 1. p. 118-124, out. 2006-mar. 2007. p. 119.

32 FERRARI, Regina Maria Macedo Nery. Necessidade de Regulamentação Constitucional. In: Caderno de Direito Constitucional e Ciência Politica, v. 18, ed. Revista dos Tribunais. p. 63.

33 DINIZ, Maria Helena. Dicionário Jurídico. São Paulo: Saraiva, 1998. v. 3. p. 371 .

34 A título de exemplo: "Não há identidade possível entre a norma que confere ao trabalhador direito ao 'seguro desemprego' em caso de desemprego involuntário (CF, art. 7º, II) e a que estatui que a família tem especial proteção do Estado (CF, art. 226). No primeiro caso, existe um verdadeiro direito. Há uma prestação positiva a exigir-se, eventualmente, frustrada pelo legislador ordinário. No segundo caso, faltando o Poder Público a um comportamento comissivo, nada lhe será exigível, senão que se abstenha de atos que impliquem a 'desproteção' da família". O mesmo exemplo pode ser aplicado à saúde. BARROSO, Luís Roberto. $O$ direito constitucional e a efetividade de suas normas. 5 . ed. Rio de Janeiro: Renovar, 2001. p. 120.

35 "Os dois conjuntos de padrões apontam para decisões particulares acerca da obrigação jurídica em circunstâncias específicas, mas distinguem-se quanto à natureza da orientação que oferecem. As regras são aplicáveis à maneira do tudo-ou-nada. Dados os fatos que uma regra estipula, então ou a regra é válida, e neste caso a resposta que ela fornece deve ser aceita, ou não é válida, e, neste caso em nada contribui para a decisão". DWORKIN, Ronald. Levando os direitos a sério. Tradução de Nelson Boeira. São Paulo: Martins Fontes, 2002. p. 39.

${ }^{36}$ Tradução livre de: "El punto decisivo para la distinción entre reglas y principios es que los principios son normas que ordenan que se realice algo en la mayor medida posible, en relación con las posibilidades jurídicas y fácticas. Los princípios son, por consiguiente, mandatos de optimización que se caracterizan porque pueden ser cumplidos en diversos grados y porque la medida ordenada de su cumplimiento no sólo depende de las possibilidades fácticas, sino también de las posibilidades jurídicas. El campo de las posibilidades jurídicas está determinado a través de principios y reglas que juegan en sentido contrario. En cambio, las reglas son normas que exigen un cumplimiento pleno y, em esa 
medida, pueden siempre ser sólo o cumplidas o incumplidas. Si uma regla es válida, entonces es obligatorio hacer precisamente lo que ordena, ni más ni menos. Las reglas contienen por ello determinaciones en el campo de lo posible fáctica y jurídicamente. Lo importante por ello no es si la manera de actuar a que se refiere la regla puede o no ser realizada em distintos grados. Hay por tanto distintos grados de cumplimiento. Si se exige la mayor medida posible de cumplimiento en relación con las posibilidades jurídicas y fácticas, se trata de un principio. Si sólo se exige una determinada medida de cumplimiento, se trata de una regla". ALEXY, Robert. Sistema jurídico, princípios jurídicos y razón práctica. Doxa - Cuadernos de Filosofia del Derecho. n. 5. p. 139-151, 1988. Disponível em: <http://www.cervantesvirtual.com/servlet/SirveObras? portal $=0 \& u r l P r o p i a=15290>$. Acesso em: 04 fev. 2013. p. 143-144.

37 Alexy, aduz: Tradução livre de: "No es fácil una comparación entre la teoría del Derecho de Dworkin y la mía. Ciertamente, hay muchas cosas comunes, pero el armazón conceptual de ambas teorías es bien distinto. Quizás pudiera decirse incluso que ambas teorías son relativamente semejantes en lo substancial, pero bastante distintas en lo formal. De todas formas, también hay diferencias sustanciales. Así, aunque el concepto de principio jurídico juega su papel $\mathrm{n}$ ambas teorías, el manejo que se hace del mismo varía. En mi concepción, los principios tienen el carácter de mandatos de optimización. Además, los bienes colectivos pueden también ser objeto de regulación de los principios. Eso lleva a que en la contestación a la pregunta de si se ha lesionado um derecho fundamental juegue un papel central el principio de proporcionalidad y, con ello, la ponderación. Las cosas son distintas en la visión de Dworkin de los derechos como triunfos ('trumps'). También hay diferencias en la determinación de las relaciones entre libertad e igualdad. Yo considero la libertad y la igualdad como principios del mismo rango que pueden entrar en colisión. Pero eso queda excluido en la visión de Dworkin de la igualdad ('equal concern') como la virtud suprema ('sovereign virtue') de la comunidad política. Para mí, el concepto que expresa la armonía a la que se aspira no es el de igualdad, sino el de corrección. Tanto la libertad como la igualdad están subordinados a esta idea regulativa." ATIENZA, Manuel. Entrevista com Robert Alexy. Doxa-Publicaciones periódicas. n. 24, 2001. Disponível em: <http://www.cervantesvirtual.com/servlet/ SirveObras/01372719768028837422802/doxa24/doxa24_28.pdf>. Acesso em: 25 jan. 2010. p. 674.

${ }^{38}$ STRECK, Lênio Luiz. Hermenêutica jurídica e $(m)$ crise: uma exploração hermenêutica da construção do Direito. 4. ed. rev. atual. Porto Alegre: Livraria do Advogado, 2003. p. 53.

39 "Caso fôssemos aferrar-nos a esta exegese de cunho estritamente literal, teríamos de reconhecer que não apenas os direitos sociais (arts. $6^{\mathrm{O}} \mathrm{a}$ 11), mas também os direitos de nacionalidade (arts. 12 e 13), bem como os direitos políticos (arts. 14 a 17) fatalmente estariam excluídos da proteção outorgada pela norma contida no art. $60, \S 4^{\circ}$, inc. IV, de nossa Lei Fundamental. Aliás, por uma questão de coerência, até mesmo os direitos coletivos (de expressão coletiva) constantes no rol do art. $5^{\circ}$ não seriam merecedores desta proteção. Já esta simples constatação indica que tal interpretação dificilmente poderá prevalecer". SARLET, Ingo Wolfgang. A eficácia do direitos fundamentais. 8. ed. Porto Alegre: Livraria do Advogado, 2007. p. 430.

40 RAICHELIS, Raquel. Gestão pública e a questão social na grande cidade. Lua Nova, São Paulo, n. 69, p. 13-48, 2006. Disponível em: $<\mathrm{http}$ ://www.scielo.br/pdf/ln/n69/a03n69.pdf >. Acesso em: 15 ago. 2010. p. 5.

41 "Os Direitos Fundamentais Sociais colocam quase sempre um problema quantitativo, relacionado ao fato de saber: quantos meios de subsistência? Quanta instrução? Quanto trabalho? Quanta habitação? Quanta saúde? Quanta educação? No limite, a questão constitucional refere-se estritamente a um problema de delimitação: como traçar os limites de um direito subjetivo sem violar o princípio da igualdade?". QUEIROZ, Cristina M. M. O Princípio da não reversibilidade dos direitos fundamentais sociais. Coimbra: Coimbra Ed., 2007. p. 67.

42 FARIA, José Eduardo (Org.). "O Judiciário e os Direitos Humanos e Sociais: notas para uma avaliação da justiça brasileira". In: FARIA, José Eduardo (Org.). Direitos humanos, direitos sociais e justiça. São Paulo: Malheiros, 1994. p. 105.

${ }^{43}$ BUCCI, Maria Paula Dallari. Direito Administrativo e politicas públicas. São Paulo: Saraiva, 2002. p. 241.

44 Veja-se "1) positivação dos direitos econômicos, sociais e culturais sob a forma de normas programáticas definidoras de tarefas e fins do Estado (Staatszielbestimmungen) de conteúdo eminentemente social; 2) positivação dos direitos econômicos, sociais e culturais na qualidade de normas de organização atributivas de competência para a emanação de medidas relevantes [...]; 3) positivação dos 'direitos sociais' através da consagração constitucional de garantias institucionais (Institucionelle Garantien), obrigando o legislador a proteger a essência de certas instituições (família, administração local, saúde pública) e a adotar medidas estritamente conexionadas com o 'valor social eminente' dessas instituições; 4) positivação dos direitos sociais como direitos subjectivos públicos, isto é, direitos inerentes ao espaço existencial dos cidadãos" CANOTILHO, José Joaquim Gomes. Estudos sobre direitos fundamentais. Coimbra: Coimbra Ed., 2004. p. 37-38.

${ }^{45}$ SARLET, Ingo Wolfgang. A eficácia dos Direitos Fundamentais. 10. ed. rev., atual. e ampl. Porto Alegre: Livraria do Advogado, 2011. p. 290.

${ }^{46}$ E mais "conferem elasticidade ao ordenamento constitucional; têm como destinatário primacial - embora não único o legislador; a cuja opção fica a ponderação do tempo e dos meios em eu vêm a ser revestidas de plena eficácia (e nisso consiste a discricionariedade); não consentem que os cidadãos ou quaisquer cidadãos as invoque já (ou imediatamente após a entrada em vigor da Constituição), pedindo aos tribunais o seu cumprimento só por si, pelo que pode haver quem afirme que os direitos que delas constam, máxime os direitos sociais, têm mais natureza de expectativa que de verdadeiros direitos subjectivos; aparecem, muitas vezes, acompanhadas de conceitos indeterminados ou parcialmente indeterminados". MIRANDA, Jorge. Manual de direito constitucional. 4. ed. Coimbra: Coimbra Ed., 1990. p. 218.

47 SARLET, Ingo Wolfgang. A eficácia dos direitos fundamentais. 2.ed. Porto Alegre: Livraria do Advogado, 2001. p. 8.

48 PIOVESAN, Flávia. Não à desconstitucionalização dos direitos sociais. Revista Consultor Jurídico, 02 de jun. 2000. Disponível em: <http:// conjur.uol.com.br/textos/2843/>. Acesso em: 10 abr. 2013.

49 "Não foi instituída a dimensão social no Tratado de Assunção, embora tenha referido o objetivo do desenvolvimento com justiça social, pois inexistem cláusulas [...] embora tenham feito uma opção, uma preferência econômica no art. $1^{\circ}$, surgiu uma tímida livre circulação de pessoas. Mais tarde dois documentos se apresentam importantes, a Resolução 44/1994 e Decisão 7/1995 do mercado comum. O que o MERCOSUL fez foi estabelecer uma área de livre comércio, ficando num segundo plano a questão social, assim como o déficit democrático no próprio processo de formação sem consulta popular". ALMEIDA, Rosângela da Silveira. Proteção social no Mercosul: a saúde dos trabalhadores de municípios fronteiriços do Rio Grande do Sul. Porto Alegre, 2008. Tese (Doutorado em Serviço Social) - Faculdade de Serviço Social, PUCRS. Orientação: Profa. Dra. Jussara M. R. Mendes. p. 47.

${ }^{50}$ Tradução livre de: "La existencia de un consenso jurisprudencial y doctrinal sobre que los derechos humanos reconocidos en los pactos y tratados tienen jerarquia constitucional (Marabotto así lo sostiene en su libro "Los derechos humanos en la jurisprudencia de la Suprema Corte de Justicia en Uruguay)". ROMERO, Graciela. Reflexiones acerca de la exigibilidad y justiciabilidad de los Derechos Económicos, Sociales y Culturales (DESC). Disponível em: <http://www.choike.org/ documentos/desc_romero.pdf $>$. Acesso em: 5 abr. 2012.

${ }^{51}$ E aqui se acompanha o raciocínio de José Joaquim Gomes Canotilho, nos seguintes termos: "A ideia aqui expressa também tem sido designada como proibição de "contra-revolução social" ou da "evolução reaccionária". Com isso quer dizer-se que os direitos sociais económicos (ex.: direito dos trabalhadores, direito à assistência, direito à educação), (acrescentese a saúde) uma vez obtido um determinado grau de realização, passam a constituir, simultaneamente, uma garantia institucional e um direito subjectivo. [...] A violação do núcleo essencial efectivado justificará a sanção de inconstitucionalidade relativamente a normas manifestamente aniquiladoras da chamada "justiça social". [...] O princípio da proibição de retrocesso social pode formular-se assim: o núcleo essencial dos direitos sociais já realizado e efectivado através de medidas legislativas [...] deve considerar-se constitucionalmente garantido, sendo inconstitucionais quaisquer medidas estaduais que, sem a criação de outros esquemas alternativos ou compensatórios, se traduzam, na prática, numa "anulação", "revogação" ou "aniquilação" pura e simples desse núcleo essencial". CANOTILHO, José Joaquim Gomes. Direito constitucional. Coimbra: Almedina, 2003. p. 338-340.

${ }^{52}$ Nesse sentido, José Joaquim Gomes Canotilho adverte: “uma vez obtido um determinado grau de realização, passam a constituir, simultaneamente, uma garantia institucional e um direito subjetivo. A "proibição de retrocesso social" nada pode fazer contra as recessões e crises econômicas (reversibilidade fática), mas o princípio em análise limita a reversibilidade dos direitos adquiridos (ex.: segurança social, subsídio de desemprego, prestações de saúde), em clara violação do princípio da proteção da confiança e da segurança dos cidadãos no âmbito econômico, social e cultural, e do núcleo essencial da existência mínima inerente ao respeito pela dignidade da pessoa humana. $\mathrm{O}$ reconhecimento desta proteção 
de "direitos prestacionais de propriedade", subjetivamente adquiridos, constitui um limite jurídico do legislador e, ao mesmo tempo, uma obrigação de prossecução de uma política congruente com os direitos concretos e as expectativas subjetivamente alicerçadas." CANOTILHO, José Joaquim Gomes. Direito Constitucional e teoria da constituição. 7. ed. Coimbra: Almedina, 2003. p. 479.

53 CANOTILHO, José Joaquim Gomes. Direito Constitucional. 6. ed. Coimbra: Livraria Almedina, 1993. p. 493.

${ }^{54}$ BARROSO, Luís Roberto. O direito constitucional e a efetividade de suas normas. 8. ed. Rio de Janeiro: Renovar, 2006. p. 152.

55 AFONSO, Túlio Augusto Tayano. Direitos sociais e princípio do não retrocesso social. Revista de Direito do Trabalho, ano 32, n. 124, p. 237-252, out.-dez. 2006. p. 243.

56 STRECK, Lênio Luis. Hermenêutica Jurídica $e(m)$ crise. Uma exploração hermenêutica da construção do direito. Porto Alegre: Livraria do Advogado, 1999. p. 31.

57 SARLET, Ingo Wolfgang. A eficácia dos direitos fundamentais. 10. ed. rev., atual. e ampl. Porto Alegre: Livraria do Advogado, 2011. p. 300-301

58 Opina a respeito o autor: "A garantia de intangibilidade desse núcleo ou conteúdo essencial de matérias (nominadas de cláusulas pétreas), além de assegurar a identidade do Estado brasileiro e a prevalência dos princípios que fundamentam o regime democrático, especialmente o referido princípio da dignidade da pessoa humana, resguarda também a Carta Constitucional dos 'casuísmos da política e do absolutismo das maiorias parlamentares"”. SARLET, Ingo Wolfgang. A Eficácia dos Direitos Fundamentais. 5.ed. Livraria do Advogado, 2003. p. 354.

59 DERBLI, Felipe. O princípio da proibição de retrocesso social na Constituição de 1988. São Paulo: Renovar, 2007. p. 298.

60 Vale a referência: "A noção de mínimo existencial, compreendida, por sua vez, como abrangendo o conjunto de prestações materiais que asseguram a cada indivíduo uma vida com dignidade, no sentido de uma vida saudável, ou seja, de uma vida que corresponda a padrões qualitativos mínimos, nos revela que a dignidade da pessoa atua como diretriz jurídico-material tanto para a definição do núcleo essencial (embora não necessariamente em todos os casos e da mesma forma), quanto para a definição do que constitui a garantia do mínimo existencial, que, na esteira de farta doutrina, abrange bem mais do que a garantia da mera sobrevivência física, não podendo ser restringido, portanto, à noção de um mínimo vital ou a uma noção estritamente liberal de um mínimo suficiente para assegurar o exercício das liberdades fundamentais, ainda mais em se tratando de um "ambiente constitucional", como é o caso do latino-americano, marcado - em termos majoritários, embora não uniformes - por um constitucionalismo socialmente comprometido, pelo menos no plano formal". "SARLET. Ingo Wolfgang. Notas sobre a assim designada proibição de retrocesso social no constitucionalismo Latino-americano. Rev. TST, Brasília, v. 75 , n. 3, jul.-set. 2009. p. 117. Disponível em $<$ http://www.tst.jus.br/ documents/1295387/1312882/7.+notas+sobre+a+assim+designada+pro $\mathrm{ibi} \% \mathrm{c} 3 \% \mathrm{a} 7 \% \mathrm{c} 3 \% \mathrm{a} 3 \mathrm{o}+\mathrm{de}+$ retrocesso + social + no + constitucionalismo +1 atino-americano>. Acesso em: 10 abr. 2013.

61 SARLET, Ingo Wolfgang. Notas sobre a assim designada proibição de retrocesso social no constitucionalismo Latino-americano. Rev. TST, Brasília, vol. 75, no 3, jul/set 2009 p. 117. Disponível em <http://www. tst.jus.br/documents/1295387/1312882/7.+notas+sobre+a+assim+desig nada+proibi $\%$ c $3 \% \mathrm{a} 7 \% \mathrm{c} 3 \% \mathrm{a} 3 \mathrm{o}+\mathrm{de}+$ retrocesso + social + no + constitucion alismo+latino-americano>. Acesso em: 10 abr. 2013.

${ }^{62}$ BARNES, Javier. Introducción al principio de proporcionalidad en el derecho comparado y comunitario. Revista de Administración Pública, Madrid, n. 135. p. 495-522, 1994. p. 510

63 Veja-se: "Haveria, em abstrato, um espaço suscetível de limitação pelo legislador e outro insuscetível de ser afetado. A teoria relativa, por sua entende que o núcleo essencial há de ser definido in casu, tendo em vista o objetivo a ser perseguido pela norma de caráter restritivo. Assim, seria definido pela utilização de um processo de ponderação entre meios e fins para aferir aquele mínimo insuscetível de restrição". MENDES, Gilmar Ferreira. Direitos fundamentais e controle de constitucionalidade. 3. ed. São Paulo: Saraiva, 2004. p. 43-44.

64 "O conteúdo mínimo dos direitos fundamentais, assim, cede espaço tanto para a deliberação judicial (hermenêutica) quanto para a deliberação política, ou seja, pode-se relegá-lo ao legislador constituinte, que o define explícita ou explicitamente no texto fundamental, e ao Poder Judiciário, na sindicabilidade das políticas públicas e da produção legislativa infraconstitucional. Sarlet defende a posição de que o núcleo essencial dos direitos fundamentais está vinculado à dignidade da pessoa humana. Por certo que na apuração da ofensa ao núcleo essencial, inclusive pela utilização da proporcionalidade, a dignidade será considerada, seja como valor, seja como princípio. [...] O núcleo essencial, assim delineado, verificável somente a partir do caso concreto e dos direitos tomados em exame, servirá de limite para a conformação legislativa na densificação normativa dos direitos fundamentais sociais". AWAD, Fahd Medeiros. Proibição de retrocesso social diante da garantia do núcleo essencial dos Direitos Fundamentais. Revista Justiça do Direito, v. 24, n. 1, 2010. p. 90-100. Disponível em: <http://www.upf.br/seer/index. php/rjd/article/ view/2146>. Acesso em: 11 abr. 2013.

${ }^{65}$ BARROSO, Luis Roberto Direito Constitucional e a efetividade das normas. 5. ed. Rio de Janeiro, Renovar, 2001. p. 158-159.

66 SARLET, Ingo Wolfgang. A eficácia do direito fundamental à segurança jurídica: dignidade da pessoa humana, direitos fundamentais e proibição de retrocesso social no direito constitucional brasileiro. 2005. Disponível em: <http://www.mundojuridico.adv.br>. Acesso em: 9 abr. 2013.

67 CANOTILHO, Joaquim José Gomes. Direito Constitucional e teoria da constituição. 3. ed. Coimbra, Portugal: Almedina, 1998. p. 221.

68 BARROSO, Luís Roberto. O direito constitucional e a efetividade de suas normas. 5. ed. Rio de Janeiro: Renovar, 2001. p. 158.

69 PIOVESAN, Flávia. Direitos humanos e o direito constitucional internacional. 4.ed. São Paulo: Max Limonad, 2000. p. 54-55.

70 HÄBERLE, Peter. Dignita Dell'Uomo e Diritti Sociali nelle Costituzioni degli Stati di Diritto. In: Costituzione e Diritti Sociali. Éditions Universitaires Fribourg Suisse, 1990. p. 99-102. Ver: SARLET, Ingo Wolfgang. Notas sobre a assim designada proibição de retrocesso social no constitucionalismo Latino-americano. Rev. TST, Brasília, v. 75, n. 3, jul.-set. 2009. p. 117. Disponível em: <http://www.tst.jus.br/docu ments/1295387/1312882/7.+notas+sobre+a+assim+designada+proibi\% $\mathrm{c} 3 \% \mathrm{a} 7 \% \mathrm{c} 3 \% \mathrm{a} 3 \mathrm{o}+\mathrm{de}+$ retrocesso + social + no + constitucionalismo+latinoamericano>. Acesso em: 10 abr. 2013.

71 SARLET, Ingo Wolfgang. Notas sobre a assim designada proibição de retrocesso social no constitucionalismo Latino-americano. Rev. TST, Brasília, v. 75, n. 3, jul.-set. 2009. p. 117. Disponível em <http://www. tst.jus.br/documents/1295387/1312882/7.+notas+sobre+a+assim+desig nada + proibi $\%$ c $3 \%$ a $7 \%$ c $3 \% a 30+$ de + retrocesso + social + no + constitucion alismo+latino-americano>. Acesso em: 10 abr. 2013.

72 SARLET, Ingo Wolfgang. Notas sobre a assim designada proibição de retrocesso social no constitucionalismo Latino-americano. Rev. TST, Brasília, vol. 75, no 3, jul/set 2009 p. 117. Disponível em <http://www. tst.jus.br/documents/1295387/1312882/7.+notas+sobre+a+assim+desig nada + proibi $\%$ c $3 \%$ a $7 \%$ c $3 \% a 30+$ de + retrocesso + social + no + constitucion alismo+latino-americano>. Acesso em: 10 abr. 2013.

73 BARCELLOS, Ana Paula de. A eficácia jurídica dos princípios constitucionais: o princípio da dignidade da pessoa humana. Rio de Janeiro: Renovar, 2002. p. 69.

74 SARLET, Ingo Wolfgang. Notas sobre a assim designada proibição de retrocesso social no constitucionalismo Latino-americano. Rev. TST, Brasília, v. 75, n. 3, jul.-set. 2009 p. 117. Disponível em <http://www. tst.jus.br/documents/1295387/1312882/7.+notas+sobre+a+assim+desig nada+proibi $\%$ c 3\%a $7 \%$ c 3\%a $30+$ de + retrocesso + social + no + constitucion alismo+latino-americano>. Acesso em: 10 abr. 2013.

75 PIOVESAN, Flávia. Direitos Econômicos, Sociais e Culturais e os desafios. Revista Consultor Jurídico, 2002. Disponível em: <http:// conjur.estadao.com.br/static/text/10798,1>. Acesso em: 9 abr. 2013.

76 MACIEL, Álvaro dos Santos. Do principio do não-retrocesso social. Disponível em: <http://www.boletimjuridico.com.br/doutrina/texto. asp?id=1926>. Acesso em: 10 abr. 2013.

77 Aduz: "A inclusão de tal proibição na ordem jurídica deu-se para impedir a violação do núcleo essencial do Texto Magno, e, por conseqüência, a supressão de normas de justiça social. Com isso, firma-se a vedação do legislador em reduzir qualquer direito social assegurado constitucionalmente, sob pena de violação do princípio de proteção da confiança e segurança dos cidadãos no âmbito social, e de inconstitucionalidade". MACIEL. Álvaro dos Santos. Do princípio do não-retrocesso social. Disponível em: <http://www.boletimjuridico.com. br/doutrina/texto.asp?id=1926>. Acesso em: 10 abr. 2013.

78 WEIS, Carlos. Direitos humanos contemporâneos. São Paulo: Malheiros, 2006. p. 100.

79 BRASILIA, Supremo Tribunal Federal, ADI n 2065-0/DF, voto do Ministro Sepúlveda Pertence. Disponível em: $<$ http://redir.stf.jus.br/ paginadorpub/paginador.jsp?docTP $=\mathrm{AC} \& \operatorname{doc} \mathrm{ID}=375320>$. Acesso em: 17 abr. 2013.

${ }^{80}$ BRASILIA, Supremo Tribunal Federal, ADI nº 2065-0/DF, voto do Ministro Sepúlveda Pertence. Disponível em: $<$ http://redir.stf.jus.br/ paginadorpub/paginador.jsp?docTP $=\mathrm{AC} \& \operatorname{doc} \mathrm{ID}=375320>$. Acesso em: 17 abr. 2013. 
81 AMAPÁ, Supremo Tribunal Federal. Are 639337 Agr, Relator(a): Min. Celso De Mello, Segunda Turma, julgado em 23/08/2011, dje177 divulg 14-09-2011 public 15-09-2011 ement vol-02587-01 PP00125. Disponível em: <http://www.stf.jus.br/portal/jurisprudencia/ listarJurisprudencia.asp?s1=\% 28sa\%FAde + reserva + do + poss $\%$ EDvel \%29\&base=baseAcordaos $>$. Acesso em: 05 abr. 2013.

82 SARLET. Ingo Wolfgang. Notas sobre a assim designada proibição de retrocesso social no constitucionalismo Latino-americano. Rev. TST, Brasília, v. 75, n. 3, jul.-set. 2009, p. 117. Disponível em <http://www. tst.jus.br/documents/1295387/1312882/7.+notas+sobre+a+assim+desig nada+proibi $\%$ c $3 \%$ a $7 \%$ c3\%a3o+de+retrocesso+social + no + constitucion alismo+latino-americano>. Acesso em: 10 abr. 2013

83 E mais: "De forma geral, o tema do princípio da proibição do retrocesso social na Alemanha esteve mais associado à crise do Estado-Providência, em especial no que concerne à proteção das posições jurídicas dos cidadãos em face da tensão entre a decrescente capacidade prestacional do Estado e da sociedade e o aumento da demanda por prestações sociais". [...] "O Bundersverfassungsgericht estendeu aos direitos patrimoniais em face do Estado a vinculação entre o direito de propriedade privada e a liberdade individual, na medida em que a liberdade na esfera patrimonial é sucedânea da autonomia de cada um para conduzir sua existência. Para que a proibição de retrocesso social alcance um determinado direito subjetivo público prestacional, não se exige equivalência entre a prestação estatal e tal contraprestação do indivíduo, mas ela tem que ser (ou haver sido) ao menos relevante". p. 142-143. DERBLI, Felipe. O princípio da proibição de retrocesso social na Constituição de 1988. São Paulo: Renovar, 2007. p. 137-143.

${ }^{84}$ CANOTILHO, José Joaquim Gomes. Direito Constitucional e Teoria da Constituição. 7. ed. Coimbra: Almedina, 2003. p. 340.

85 "Recorde-se, por exemplo, que o artigo 50 da Constituição dizia, no seu texto inicial, que "a apropriação colectiva dos principais meios de produção, a planificação do desenvolvimento económico e a democratização das instituições são garantias e condições para a efectivação dos direitos e deveres económicos, sociais e culturais". E, em comentário a este preceito, afirmava-se que a realização dos direitos em causa "supõe, assim, directamente, uma ruptura com a ordem capitalista e com a estrutura oligárquica da sociedade e do Estado". Por conseguinte, o princípio da proibição do retrocesso social - tal como o princípio da irreversibilidade das nacionalizações, em relação à apropriação colectiva dos meios de produção - apresentava-se como uma garantia dos direitos sociais enquanto instrumentos para alcançar progressivamente o socialismo. No fundo, estava em causa uma concepção de direitos sociais (e do Estado social) como "cavalo de Tróia" do socialismo". SILVA, Jorge Pereira da. Dever de legislar e protecção jurisdicional contra omissões legislativas: contributo para uma teoria da inconstitucionalidade por omissão. Lisboa: Universidade Católica, 2003. p. 248-249.

${ }^{86}$ CANOTILHO, José Joaquim Gomes. Direito constitucional. 6. ed. Coimbra: Almedina, 1993. p. 542.

${ }^{87}$ CANOTILHO, José Joaquim Gomes. Direito constitucional. 6. ed. Coimbra: Almedina, 1993. p. 542.

88 E mais, "O relator da questão, Conselheiro Vital Moreira, rejeitou a tese de inconstitucionalidade formal e passou à análise da inconstitucionalidade material do art. 17 do Decreto-Lei no 254/82. Entendeu o Conselheiro que, ao instituir o SNS, a Lei no 56/79 era um meio de realização do direito fundamental à proteção à saúde com consagração no art. 64 da Constituição e que, mediante o art. 17 do Decreto-Lei no 254/82, o Governo legislara sobre direito à saúde e extinguira o SNS. Ao proferir seu voto, Vital Moreira tratou dos direitos sociais, especialmente os de proteção à saúde, como direitos fundamentais, observando que estes não possuem natureza semelhante a dos direitos, liberdades e garantias, isto é, dos direitos de liberdade, dos direitos políticos e das garantias constitucionais. Em relação aos direitos sociais, aduziu o relator que se acentua o seu caráter positivo ao exigir prestações positivas do Estado, sem que se negue a jusfundamentalidade desses direitos sociais. Partindo dessas manifestações, o relator desenvolveu os argumentos da proibição de retrocesso social, afirmando a inconstitucionalidade do debatido art. 17 do Decreto-Lei no 254/82." FILETI, Narbal Antônio Mendonça. O princípio da proibição de retrocesso social. Breves considerações. Jus Navigandi, Teresina, ano 14, n. 2059, 19 fev. 2009. Disponível em: $<\mathrm{http} / / /$ jus.com.br/revista/texto/12359>. Acesso em: 9 abr. 2013.

${ }^{89}$ SARLET. Ingo Wolfgang. Notas sobre a assim designada proibição de retrocesso social no constitucionalismo Latino-americano. Rev. TST, Brasília, v. 75, n. 3, jul.-set. 2009 p. 117. Disponível em: <http://www. tst.jus.br/documents/1295387/1312882/7.+notas+sobre+a+assim+desig nada+proibi $\%$ c $3 \% a 7 \%$ c3\%a3o+de+retrocesso+social + no+constitucion alismo+latino-americano>. Acesso em: 10 abr. 2013.
${ }_{90}$ BOBBIO, Norberto. Era dos Direitos. Rio de Janeiro: Campus, 1992. p. 77-78.

91 ALMEIDA, Dayse Coelho de. A fundamentalidade dos direitos sociais e o princípio da proibição de retrocesso. Inclusão Social, Brasília, v. 2, n. 1, p. 118-124, out. 2006/ mar. 2007. p. 122.

92 ALMEIDA, Dayse Coelho de. A fundamentalidade dos direitos sociais e o princípio da proibição de retrocesso. Inclusão Social, Brasília, v. 2, n. 1, p. 118-124, out. 2006-mar. 2007. p. 122.

${ }^{93}$ FILETI, Narbal Antônio Mendonça. O princípio da proibição de retrocesso social. Breves considerações. Jus Navigandi, Teresina, ano 14, n. 2059, 19 fev. 2009. Disponível em: <http://jus.com.br/revista/ texto/12359>. Acesso em: 9 abr. 2013.

${ }^{94}$ GOLDSCHMIDT, Rodrigo. O princípio da proibição do retrocesso social e sua função protetora dos direitos fundamentais. Disponível em $<\mathrm{http}$ ://editora.unoesc.edu.br/index.php/seminarionacional dedimensoes/ article/view/906/521>. Acesso em: 11 abr. 2013.

95 GOLDSCHMIDT, Rodrigo. O princípio da proibição do retrocesso social e sua função protetora dos direitos fundamentais. Disponível em $<$ http://editora.unoesc.edu.br/index.php/seminarionacional dedimensoes/ article/view/906/521>. Acesso em: 11 abr. 2013.

${ }^{96}$ Ementa do Acórdão: CIVIL E CONSTITUCIONAL. ENSINO PARTICULAR. DESCONTO DAMENSALIDADE. SEGUNDO FILHO.APLICAÇÃO AO ENSINO UNIVERSITÁRIO. 1. O art. 24 do DL 3.200/41 foi concebido para beneficiar famílias de prole numerosa, garantindo o acesso de todos ao ensino. Repasse do custo às mensalidades (art. 205 da CF). Aplicação do texto ao ensino universitário (art. 208, V, e 209, I, da CF). 2. O dispositivo em questão nada mais é do que uma conquista social da época e que não foi derrogado pela legislação ou Constituições supervenientes, pois nenhuma destas normas mostra-se incompatível ou regula inteiramente a matéria que tratava a lei anterior (art. $2^{\mathrm{o}}$ da LICC). Manteve-se íntegro no tempo, obediente ao princípio da proibição do retrocesso social defendido por J. J. Canotilho. Apelo improvido". In: GOLDSCHMIDT, Rodrigo. O principio da proibição do retrocesso social e sua função protetora dos direitos fundamentais. Disponível em: <http://editora.unoesc.edu. br/index.php/seminarionacional dedimensoes/article/view/906/521>. Acesso em: 11 abr. 2013 p. 285.

${ }^{97}$ Adverte Rodrigo Goldchmidt: "No corpo do mencionado Acórdão, o órgão julgador salienta que o dispositivo legal que assegura descontos nas mensalidades escolares para aquelas famílias com mais de um filho matriculado no mesmo estabelecimento de ensino nada mais é do que uma conquista social da época, que pretendia beneficiar as famílias de prole numerosa, em consonância com o disposto na Constituição de 1937, a qual estabelecia que a gratuidade do ensino não excluiria o dever de solidariedade dos menos para os mais necessitados. Em face disso, fundamenta, ainda, o referido órgão julgador: “[...] o artigo 24 do Decreto-Lei 3.200/41 manteve-se íntegro no tempo, obediente ao princípio da proibição do retrocesso social defendido por J. J. Canotilho, segundo o qual, os direitos sociais e econômicos (direito dos trabalhadores, direito à assistência, direito à educação), uma vez alcançados ou conquistados, passam a constituir, simultaneamente, uma garantia constitucional e um direito subjetivo, protegidos da livre e oportunística disposição do legislador no sentido de diminuir ou restringir ditos direitos adquiridos." GOLDSCHMIDT, Rodrigo. O princípio da proibição do retrocesso social e sua função protetora dos direitos fundamentais. Disponível em $<\mathrm{http}: /$ editora.unoesc.edu.br/index.php/seminarionacional dedimensoes/article/ view/906/521>. Acesso em: 11 abr. 2013.

98 SARLET. Ingo Wolfgang. Notas sobre a assim designada proibição de retrocesso social no constitucionalismo Latino-americano. Rev. TST, Brasília, v. 75, n. 3, jul.-set. 2009. p. 117. Disponível em $<$ http://www. tst.jus.br/documents/1295387/1312882/7.+notas+sobre+a+assim+desig nada + proibi $\%$ c $3 \%$ a $7 \%$ c $3 \% \mathrm{a} 3 \mathrm{o}+$ de + retrocesso + social + no + constitucion alismo+latino-americano>. Acesso em: 10 abr. 2013.

${ }^{99}$ STRECK, Lenio Luiz. Jurisdição constitucional e hermenêtica: uma nova crítica do direito. 2. ed. Rio de Janeiro: Forense, 2004. p. 706.

${ }^{100}$ SARLET. Ingo Wolfgang. Notas sobre a assim designada proibição de retrocesso social no constitucionalismo Latino-americano. Rev. TST, Brasília, v. 75, n. 3, jul.-set. 2009, p. 117. Disponível em: <http://www. tst.jus.br/documents/1295387/1312882/7.+notas+sobre+a+assim+desig nada + proibi $\%$ c $3 \% a 7 \%$ c3\%a3o+de+retrocesso + social + no + constitucion alismo+latino-americano>. Acesso em: 10 abr. 2013. p. 126

${ }^{101}$ MIRANDA. Jorge. Manual de Direito Constitucional. Coimbra: Coimbra, 2000. p. 397 e ss.

${ }^{102}$ SARLET. Ingo Wolfgang. Notas sobre a assim designada proibição de retrocesso social no constitucionalismo Latino-americano. Rev. TST, Brasília, v. 75, n. 3, jul.-set. 2009, p. 113. Disponível em <http://www. tst.jus.br/documents/1295387/1312882/7.+notas+sobre+a+assim+desig 
nada + proibi $\%$ c $3 \% \mathrm{a} 7 \% \mathrm{c} 3 \% \mathrm{a} 3 \mathrm{o}+\mathrm{de}+$ retrocesso + social + no + constitucion alismo+latino-americano>. Acesso em: 10 abr. 2013.

${ }^{103}$ Por analogia a seara social, também a seara ambiental, adverte Carlos Alberto Molinaro, que "falar de um princípio de vedação da retrogradação, já que o Direito Ambiental cuida justamente da proteção e promoção dos bens ambientais, especialmente no sentido de impedir a degradação do meio ambiente, o que corresponde, por sua vez, a uma perspectiva evolucionista (e não involucionista) da vida”. MOLINARO, Carlos Alberto. Direito Ambiental: proibição de retrocesso. Porto Alegre: Livraria do Advogado, 2007. p. 91 e ss Ver também: MOLINARO, Carlos Alberto. Racionalidade Ecológica e Estado Socioambiental e Democrático de Direito. Dissertação (Mestrado) - Programa de PósGraduação em Direito da Faculdade de Direito da Pontifícia Universidade Católica do Rio Grande do Sul, 2006.

${ }^{104}$ AWAD, Fahd Medeiros. Proibição de retrocesso social diante da garantia do núcleo essencial dos Direitos Fundamentais. Revista Justiça do
Direito, v. 24, n. 1, p. 90-100, 2010. Disponível em: <http://www.upf.br/ seer/index.php/rjd/article/view/2146>. Acesso em: 11 abr. 2013.

${ }^{105}$ SARLET, Ingo Wolfgang. A eficácia dos direitos fundamentais. 10. ed. rev., atual. e ampl. Porto Alegre: Livraria do Advogado, 2011. p. 299.

${ }^{106}$ MÉNDEZ, Emílio Garcia. Origem, sentido e futuro dos direitos humanos: reflexões para uma nova agenda. Revista Internacional de Direitos Humanos, Rede Universitária de Direitos Humanos - SUR, ano 1, n. 1, p. 12-13, $1^{\circ}$ sem. 2004.

${ }^{107}$ BOVEN, Theodoor C. Van. Os critérios de distinção dos direitos do homem. In: VASAK, Karel. As dimensões internacionais dos direitos do homem. Tradução de Carlos Alberto Aboim de Brito. Lisboa: Editora Portuguesa de Livros Técnicos e Científicos, 1983. p. 60.

${ }^{108}$ VASCONCELOS, Marcos Cesar Santos. As decisões normativas na jurisdição constitucional. Dissertação (Mestrado) - Instituto Brasiliense de Direito Público - IDP, Brasília, 2010. p. 35. 